\title{
NARROW-GAUGE RAILWAYS, OF TWO FEET GAUGE AND UNDER.
}

By Mr. LESLIE S. ROBERTSON, OF LoNDON.

The circumstance that the Members of the Institution are to have the opportunity, through the courtesy of Sir Arthur Percival Heywood, Bart., of inspecting an interesting example of a very Narrow-Gauge Line of his own design, for which all the details, mechanical and otherwise, have been carefully thought out by its designer-and the coincidence that this meeting of the Institution is being held under the presidency of one of the leading locomotive engineers of this country-render the present a favourable opportunity for bringing before the Institution some facts in connection with this class of Light Railways. The whole subject of light railways cannot be treated within the limits of the present short paper, which is confined to narrow-gauge railways of two feet gauge and under: although the author is personally of opinion that the circumstances which would justify the adoption of a gauge under two feet must be of an exceptional character. Comparatively few engineers realise the capability of narrow-gauge railways, and the saving that can be effected by their adoption, when applied to large industrial undertakings. Several instances have come under the author's notice, where the judicious adoption of light narrow-gauge lines, such as those dealt with in this paper, has resulted in considerable financial benefit to those concerned in them.

Reasons for adoption.-Narrow-gauge lines of this class may be roughly divided into two categories :-first, where the work to be done is of a permanent and constant nature, enabling the line to be laid down as a fixture; and second, where the work is of a temporary character. Under the first head might be included lines for industrial 
purposes, and the ordinary permanent light narrow-gauge railways; under the second head, military lines, contractors' lines, and so forth. These little railways enable materials to be transported from one place to another with a minimum expenditure of power and money; but it must be borne in mind that, like every other mechanical appliance, in order to be efficient they must be properly designed for the purposes they have to fulfil, and must not be a heterogeneous collection of rolling stock picked up at random, nor be treated as a standard-gauge line on a small scale.

The reduction effected in the power necessary to move any weight is clearly illustrated by the following figures, which represent a fair approximation to the power necessary for drawing a lond $W$ :- on a bad road $0.1 \mathrm{~W}$; on a good road $0.03 \mathrm{~W}$; on rails $0.006 \mathrm{~W}$. These figures show that on a level about five times the power required for traction on rails is necessary to draw the same weight on a good road, and nearly seventeen times on a bad road. Another formula gives the following results, where a load of 1,320 lbs. drawn by a horse on a level country road is taken as unity :-

TABLE 1.-Loads hauled by one Horse.

\begin{tabular}{|c|c|c|c|}
\hline $\begin{array}{c}\text { Lnad 1,320 lbs. } \\
\text { taken as unity. }\end{array}$ & $\begin{array}{c}\text { Country } \\
\text { road. }\end{array}$ & $\begin{array}{c}\text { Metalled } \\
\text { road. }\end{array}$ & Tramway. \\
\hline Level. . . & 1.0 & 3.3 & 16.7 \\
Up 1 in 100... & 0.86 & 2.4 & 5.4 \\
Up 1 in 50.... & 0.7 & 1.8 & 3.5 \\
Lp 1 in 20... . & 0.5 & 0.9 & 1.3 \\
\hline
\end{tabular}

Advantages.-The heavy expense of cartage over bad roads, and of plank and barrow work, is in itself a sufficiently strong argument for the adoption of rails, more particularly if the work has to be done rapidly; and yet it is surprising to notice how slow is the 
appreciation of the facilities afforded by the adoption of light railways. A narrow-gauge light railway should be viewed as a mechanical applianee for carrying out work, which no doubt can be done, and is being done, by inefficient mechanical appliances but at greatly enhanced cost. The same arguments which have led to the substitution of labour-saving appliances, machine-tools, \&c., in place of manual labour, apply with equal force to light railways, and should ultimately lead to their more extended adoption.

Disadrantages.-The principal disadrantages associated with narrow-gauge light railways lie no doubt firstly in the difficult question of the break of gauge, entailing as it dees trans-shipment, which will be dealt with later on; and secondly in their comparatively small carrying capacity and low speeds. Moreover, should the traffic increase to any large extent, the light line might ultimately have to be superseded by a standard-gange railway; this point will be dealt with under the financial aspect of the question.

Gauge.-When the adoption of a light railway is under consideration, one of the most difficult questions that has to be decided is that of the most suitable gauge. Narrowing the gaugo reduces the cost of construction, but at the same time reduces the carrying and earning capacity of the line. Widening the gauge improves the carrying capacity and the passenger facilities of the line, but increases the cost of construction. The selection of the most suitnble gauge must therefore be largely determined by financial considerations. Again the gauge has a considerable influence on the speed: but in most instances the circumstances which warrant the adoption of a narrow-gauge light line are such that speed of transit is not of cardinal importance. The number of different gauges which are at present being put forward for light lines is detrimental in the author's opinion to the general extension of these lines; and steps should be taken to settle upon one, or at most two, standard gauges, when the ordinary 4 -foot $8 \frac{1}{2}$-inch gauge has to be departed from. The following particulars of railways under 2 feet gange may be of interest. 
Duffield Bank Railway.-Under the circumstances of the present meeting of the Institution it is natural that the first examples should be the Duffield Bank and Faton Hall railways. The problem that Sir Arthur Heywood set himself to solve was to determine the narrowest gauge that could be adopted consistent with efficiency, for dealing at the lowest cost with an annual traffic of about 5,000 tons.

The Duffeld Bank line is of 15-inch gauge, and was laid in the first instance with 14-1b. rails; but this weight has subsequently been increased to 22 lbs. per yard, and the sleepers have been increased from 5 inches by 2 inches by $2 \frac{1}{2}$ feet to $6 \frac{1}{2}$ inches by $2 \frac{1}{2}$ inches by 3 feet, being spaced 18 inches to 2 feet apart. There is a timber viaduct 91 feet long and 20 feet high, costing $£ 1$ per yard, Plate 80 . The experimental portion of the line is arranged in the form of a figure 8 , so that experimental runs of considerable duration may be made. The curves and gradients on the line are sharp and steep, Plates 78 and 79. The locomotives, Plates 75 and 76 , embody several features of interest, more particularly the arrangements adopted for a flexible wheel-base, Plate 77, and for allowing the connecting-rod brasses to turn in the straps. The rolling stock consists mainly of small wagons, having a platform $2 \frac{1}{2}$ feet by 5 feet, to which can be fitted wooden sides or rims 8 inches deep, so arranged that they can be placed one on the top of another to any desired height, Plate 78. The passenger cars, Plate 80 , are wonderfully roomy, considering the gauge; they include a small dining car for eight persons, and a sleeping car.

The Eaton Hall line, built by Sir Arthur Heywood for the Duke of Westminster, is also of 15-inch gange, and similar to the Duffield Bank railway. It is $4 \frac{1}{2}$ miles long, and cost, including rolling stock, $£ 1,309$ per mile. One of the locomotives is shown in Plate 76, and the junction with the Great Western Railway in Plate 81.

Darjeeling Railway.-This line is of 1 foot $11 \frac{1}{2}$ inches gauge, 51 miles long, situated in the Himalayas. The average gradients are 1 in 29 , with 70 -foot curves. It rises 6,600 feet in 40 miles. The line was laid in the first instance with $30-1 b$. rails, but where 
renewals have been necessary 40-1b. rails have been substituted. The cars have a tare of about 1 ton, and carry a load of $3 \frac{1}{2}$ tons on wheels 18 inches diameter. The capital cost of the line was about $£ 4,000$ per mile, due largely to the hilly nature of the country; the receipts amount to $\$ 750$ per mile per annum, and yield a profit of 8 per cent. Two of the locomotives are shown in Plate 83. [See page 402.]

Pithiviers Raitway.-The Pithiviers line of 60 centimetres or 1 foot $11 \frac{1}{2}$ inches gange is a purely agricultural line, constructed by the Decauville Company for the carriage of beet in France. It is 19 miles long, and is laid along the side of a road. Originally 19-lb. rails were employed, but these are gradually being replaced with 24-lb. rails, when renewals become necessary. The cost per mile was about $£ 1,550$.

Caen, Dives, and Luc Railway.-This is also a Decauville line, of 60 centimetres or 1 foot $11_{2}^{1}$ inches gauge, and has a genoral agricultural and pleasure-passenger traffic. It forms a junction with the Western Railway of France, where the narrow-gauge line runs alongside the normal gauge. The cost of construction, rolling stock, telephones, \&c., was $£ 2,143$ per mile, and the line pays a dividend of about 7 per cent. Two of the locomotives are shown in Plate 82.

Festiniog Railway,-The Festiniog line is perhaps the best known light railway in this country. The initial cost was heavy, being about $£ 10,720$ per mile, although the gauge is only 1 foot $11_{\frac{1}{2}}$ inches ; but even under this condition it pays a dividend of over 5 per cent. Some of the locomotives employed arc of the Fairlie pattern, weighing 24 tons, and capable of hauling a load of 20 tons up an incline of 1 in 20 . The average speed is about 15 miles per hour.

Lynton and Barnstaple Railway.-Particulars kindly supplied by Mr. Frank W. Chanter, the engineer of this line of 1 foot $11 \frac{1}{2}$ inches gauge, are given in the appendix, pages $385-6$. 
Military Railways. - The French and German governments have both adopted 60 centimetres or 1 foot $11 \frac{1}{2}$ inches as their standard gauge for military purposes; and the German government has also settled upon this gauge for all future extensions of light railways. This has been done in order to obtain important military advantages. In the German field-railways the rails weigh 20 lbs. per yard, and both iron and wood sleepers are used; but in France the Decauville system, with the rails riveted to the sleepers, has been adopted. The German locomotives are of the Fairlie pattern, weighing 15 tons in running order, with a tractive force of 2 tons; and the rolling stock is preferably of bogie type. The 2-foot gauge has also been adopted by the government as the standard narrow gange for military purposes in India.

Light Lines in large Engineering Works.-The use of narrowgauge lines in large engineering works has not received the attention it merits. Many of the leading locomotive works, such as Crewe, Horwich, Beyer Pencock \& Co., have complete light railways with 18-inch gauge. Woolwich Arsenal is fitted with a complete system of narrow-gauge lines, of which the particulars given in the appendix (pages 386-9) have been kindly furnished by the traffic manager, Lieut. Leggett, R.E. There is also a complete line of 22-inch gauge at Guinness's Brewery in Dublin, of which a full description was given by Mr. Geoghegan at the Dublin meeting of the Institution ten years ago (Proceedings 1888, page 327). Some of the large ship-yards have also their light lines; but generally speaking the sums annually expended in the transport of material could be considerably reduced by the adoption of an efficient light railway.

Permanent Way.-The construction of the permanent way, as regards ballast, width of formation, \&c., may be looked upon as pertaining more particularly to the purely civil engineering aspect of the question, and need not therefore be dealt with here. It must however be in keeping with the weight of the engines and rolling stock. The selection of the most suitable weight of rail is one which intimately affects mechanical engineers, because on this largely 
depend the smoothness of rumning and the cost of repairs of the engines and rolling stock. Reducing the weight of rail bas comparatively little influence in diminishing the first cost, but has a decided influence in impairing the efficiency of the line as a whole, and in increasing the expenses of maintenance. The weight of rail should be dependent upon the weight peraxle, and this latter should be kept as uniform as possible. On some existing lines the weight per axle is unevenly distributed, to the detriment of the permanent way. In the vast majority of cases the weight per axle of the carriages and wagons could with advantage be increased, thereby adding to the carrying capacity of the rolling stock, and enhancing the comfort of the passenger accommodation; and the weight per axle of the locomotives might be more evenly distributed. A safe and handy rule for light lines is an allowance of 6 to 7 lbs. per yard of rail for every ton carried per axle. The question as to whether wooden or metal sleepers should be used depends mainly on the country through which the line passes, and the conditions under which it is working. The adoption of metal sleepers is recommended by the author in all cases, except where local circumstances, such as cost and climate, prohibit their use. Various methods of attaching the rail to the metal sleepers have been adopted, such as riveting, bolting, and different forms of clips and other attachments. The essential features to be studied are simplicity, rigidity, absence of repairs, and cheapness of construction.

Locomotives.-The construction of locomotives for these lines is one of the points thatiwill be of particular interest to members of this Institution, from the fact that the narrowness of the gauge introduces into the problem of their design several difficulties which are absent from larger locomotives. Although it is incompatible with the scope of this short paper to enter at any great length into particulars of design, the following points may. be noted. It is always desirable to have more than four wheels even in the lightest engines, as it is found that locomotives having only four wheels are more destructive to the road than those with six or more wheels. This point has heen emphasised in the instance of the Duffield Bank line on which 
a six-wheeled locomotive is in use, Plate 75 , as against a fourwheeled locomotive on the Eaton Hall line, Plate 76, the latter being found much more destructive to the road. The speed required on light railways is usually not great, and this should be borne in mind when the proportions of the locomotives are being decided. Their tractive power must necessarily vary with the design: the oxamples in Table 2 may bo of interest.

TABLE 2.-Proportions of Locomotives in use.

\begin{tabular}{|c|c|c|c|c|c|c|}
\hline Name of Railway. & 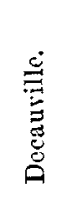 & 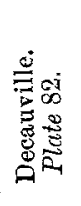 & 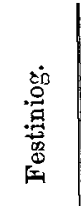 & 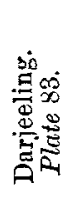 & 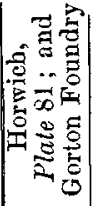 & 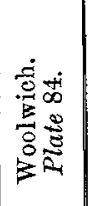 \\
\hline Gauge of railway . . . ft. ins. & 20 & 20 & 20 & 20 & 16 & 16 \\
\hline Weight of rails . lbs. per yard & 20 & $26 \frac{1}{2}$ & 80 & 40 & .. & 30 \\
\hline Diameter of cylinders & $8 \frac{1}{4}$ & $9 \frac{7}{8}$ & 9 & 11 & 5 & 7 \\
\hline Stroke of cylinders & $11 \frac{3}{4}$ & $12 \frac{1}{2}$ & 14 & 14 & 6 & 12 \\
\hline Diameter of coupled wheels, ft. ins. & 20 & $2 \quad 1 \frac{1}{2}$ & 28 & 22 & $1 \quad 4 \frac{1}{4}$ & 20 \\
\hline Number of wheels. . . & four & eight & four & four & four & 4 and 6 \\
\hline Rigid wheel-base . . . ft. ins. & 30 & 47 & 54 & 56 & 29 & .. \\
\hline Coal capacity . . . . cwts. & 25 & 30 & 12 & .. & .. & $\cdots$ \\
\hline Water capacity . . . galls. & 760 & 900 & 380 & 600 & 25 & .. \\
\hline $\begin{array}{l}\text { Weight of engine } \\
\text { in working order . . . tons }\end{array}$ & $8 \frac{1}{2}$ & 13 & $14 \frac{1}{4}$ & $13 \frac{3}{4}$ & $3 \frac{1}{3}$ & 8 \\
\hline 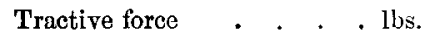 & 2240 & 3360 & 3543 & 5000 & $\cdots$ & $\cdots$ \\
\hline 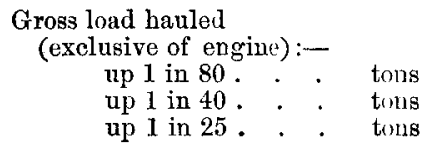 & $\begin{array}{l}61 \\
30 \\
16\end{array}$ & $\begin{array}{l}92 \\
45 \\
25\end{array}$ & $\begin{array}{l}98 \\
48 \\
27\end{array}$ & $\begin{array}{l}137 \\
66 \\
37\end{array}$ & $\begin{array}{l}\cdots \\
\cdots \\
\cdots\end{array}$ & $\begin{array}{l}\ddot{30} \\
\ldots\end{array}$ \\
\hline $\begin{array}{l}\text { Radius of curves round whic!. } \\
\text { engine will pass freely } \cdot .\end{array}$ & 49 & 82 & 70 & 70 & $\cdots$ & $\cdots$ \\
\hline
\end{tabular}

Light-railway locomotives have a greater tractive power in proportion to their gauge than standard-gange locomotives; and as the curves on light lines are usually sharp, the wheel-base must necessarily be more flexible and also shorter. 
Carriages and Wagons.-The rolling stock must naturally be of various kinds, for mecting the different conditions it is required to fulfil. Carriages may be made more roomy than would perhaps be expected at first sight. Comfortable first, second, and third-class carriages can be provided, holding up to as many as thirty passengers. Bogie stock for passenger traffic is always to be preferred, on account of the greater smoothness of running. The design of the wagons must depend on the class and quantity of goods to be conveyed. One great point in favour of light railways over those of the standard gauge is the low tare of the wagons, amounting in many cases to less than one-third of the carrying capacity of the wagon. This is an important point, because it means a larger proportion of paying load for the gross load hauled, of which the saving effect is felt throughout the entire life of the railway. The breadth and capacity of narrow-gauge rolling stock are much greater in proportion to the gauge than they can be in the standard-gauge rolling stock.

Break of Gauge and Trans-shipment.-In the vast majority of cases, a gauge of 2 feet or under must necessitate the trans-shipment of goods, if the smaller line is working in conjunction with a standard-gauge railway. Much has been written on this subject; but it is sufficient here to remark that, as a rule, too much importance has been attached to trans-shipment, and that, if thoroughly looked into, it will not be found to be so serious a difficulty. The cost does not usually exceed one penny or twopence per ton; and in many instances mechanical devices are provided for obviating any actual trans-shipment of the goods themselves.

Financial Aspects.-Light railways are only a means to an end; and the best design is that which will enable the end to be attained in a thorough and efficient manner and at the least possible cost. It is no good putting down an expensive standard-gauge line, if the expected receipts per mile will not warrant a capital expenditure of more than $£ 2,000$ or $£ 2,500$ per mile. If the transport of material costs one shilling per ton-mile, a considerable reduction 
can be effected by a narrow-gauge line, for which the necessary initial outlay will be more than compensated by the saving effected. In one instance with which the author has had to deal, the substitution of a light narrow-gauge railway to perform the work previously done by cartage and manual labour reduced the cost per ton-mile from one shilling to fivepence.

Conclusions.-The use of narrow-gauge light railways, the author is convinced, has not always received the attention it merits at the hands of Mechanical Engineers who are responsible for the equipment and conduct of large works; and large sums are annually expended in the transport of material by inefficient, slow, and expensive methods. Furthermore, a great deal of the prejudice that exists in this country against light narrow-gauge railways is due to ignorance, which would disappear if such railways were properly designed to meet the requirements of each case, when they would form a most efficient means of transport. Lastly, the main consideration influencing the adoption or rejection of light-railway schemes is financial; and no general hard and fast rules can be laid down, each case having to be considered and dealt with on its own merits. In submitting these few remarks to the members of the Institution, the author wishes it to be clearly understood that he does not advocate the general adoption of gauges under 2 feet; nor is the present paper intended to deal with the subject in an exhaustive manner.

\section{Appendix.}

\section{Lynton and Barnstaple Railway.}

This is the latest addition to railways of 1 foot $11 \frac{1}{2}$ inches or 60 centimetres gauge, and is $19 \frac{1}{2}$ miles in length, while in a straight line the distance between its termini is $14 \frac{3}{4}$ miles. It was opened 
for traffic in May 1898, having taken two years to construct. The country through which it passes is hilly, the ravines are deep, and the cross valleys numerous. There are two viaducts, of which the larger has eight spans of 45 feet, and at its highest point the rail level is 80 feet above the ground. There are no tunnels, but the cuttings and embankments are heary. The line rises nearly 800 feet in seven miles, though the maximum gradient is only 1 in 50 ; the total rise is just 1,000 feet. The curves are numerous, many being of 5 or 6 chains radius (110 to 132 yards), with $3 \frac{1}{2}$ chains (77 yards) for turn-outs and crossings. The permanent way is laid with 40-lb. steel rails, spiked and dogged to sleepers of $9 \times 4 \frac{1}{2}$ inches section, which are spaced one yard from centre to centre. The cost of construction was about $£ 2,500$ per mile, exclusive of land and rolling stock. The passenger carriages are 35 feet long and 6 feet wide, with bogie frames and roller bearings throughout. The thirdclass carriages seat 56 passengers each, and a good many first and third-class have open verandals. The goods wagons, closed and open, are 10 feet long by 5 feet wide; and there are also some open that are 25 feet long, which are on bogies. The locomotives are six-wheel-coupled, with two-wheel bogies in front and behind, and weigh 22 tons in running order; they are calculated to take a load of 50 tons up an incline of 1 in 50 at 20 miles an hour. At present the service consists of six trains a day each way, and the speed averages about 16 miles an hour, exclusive of stoppages at four intermediate stations.

\section{Woolwich Arsenal Shop Railways.}

The Rojal Arsenal at Woolwich possesses probably the most complete system of shop railways to be found in any engineering works in the country. It serves to connect 400 acres of shops, storehouses, magazines, and depôts, between which there must be ready and efficient means of communication. These railways comprise about 55 miles of line, of which about 30 miles are of 18 -inch gauge, and the remainder of 4 feet $8 \frac{1}{2}$ inches and 18-inch combined, in order that the traffic from the main standard-gauge railways may be dealt 
with as far as possible without trans-shipment. There are thirtysix locomotives of 18-inch gauge, nine of 4 feet $8 \frac{1}{2}$ inches, and a special Hornsby-Akroyd oil locomotive for uso in the neighbourhood of magazines and other dangerous places. The rolling stock consists of about 1,000 vehicles, of which two-thirds are for the 18-inch gauge and the remainder for the $4 \mathrm{ft} .8 \frac{1}{2}$ ins. The arsenal is served by a main narrow-gauge line worked similarly to the inner circle of the Metropolitun and Metropolitan District Railways, with branches to the outlying groups of stores. The whole system is divided up into six sections, with a çomplete service of trains, telephonic communication, traffic manager's office, and necessary staff. A truck can be supplied to any shop, loaded there, taken to the junction, and thence by the main line to any other section, and so to its destination in one hour from the time of its requisition. The number of trucks passing daily over the main narrow-gauge line averages about 400 , or say 2,000 tons, exclusive of any special coal traffic, and of the shifting of material inside the shops themselves. There is a passenger train running round regularly every half-hour on the narrow-gauge main line, with stoppages at $\frac{1}{4}$-mile intervals. Including depreciation of plant and its proportion of permanent-way repairs, it is calculated that this one train effects a saving of $\$ 450$ per annum. Regular workmen's open-car services on the same line represent a daily traffic of 3,200 passenger-miles, and cost about $£ 200$ per annum.

Locomotives.-Four classes of locomotives of 18-inch gauge are in daily use. (1) Heavy and powerful main-line engines built by Hudswell and Clarke, Plate 84. These are coupled engines with two axles only, and weigh 9 tons, having saddle tank, and cylinders 7 inches diameter by 12 inches stroke; they work smoothly round curves of 50 feet radius, and can if necessary go round 35-foot curves. (2) Tank engines built by Bagnall, with cylinders $7 \frac{1}{2}$ inches diameter by 12 inches stroke, having four wheels coupled and a trailing bogie. The weight on each driving axle is $8,500 \mathrm{lbs}$, and on the bogie a total of $6,000 \mathrm{lbs}$. These engines are found to be rather apt to leave the rails, the bogie arrangement not being entirely satisfactory for the work. (3) Four-wheel-coupled saddle- 
tank engines weighing 14,000 lbs., with cylinders 6 by 8 inches, built by Manning and Wardle, are found most useful for shop work, Plate 84. (4) Bagnall's Ajax engines, built specially for the War Office and to their designs, Plate 84.

The Hornsby-Akroyd locomotive is of $8 \frac{1}{2}$ brake horse-power, and burns about one gallon of common petroleum per hour when running.

Rolling Stock.-.The rolling stock is mounted on four-wheel standard cast-iron bogies, and consists of platform wagons, upon which are built up ballast trucks, covered ammunition vans, Plate 85, \&c. The total load per axle does not exceed 4 tons; that is, a 5-ton live load for the trucks built on a single bogie, and a 10-ton live load for the double-bogie wagons.

Permanent Way.-The rails are all flat-footed. The section adopted upon the Indian State Railways, weighing $41 \frac{1}{4}$ lbs. per yard, is employed for general use in the shops, and $56 \mathrm{lbs}$. per yard for the main line; and the Belgian State Railway section weighing 105 lbs. per yard is used in places where the weights are especially heary, and where the load may run up to 10 tons per axle. This heaviest section is only on the 25 miles of combined $4 \mathrm{ft}$. $8 \frac{1}{2}$ ins. and 18-inch gauge. The slcepers are of wood; Jarrah wood is now under trial. At one time tram-plates were extensively laid on the 18-inch gauge; but they have a detrimental effect on the wheels of the locomotives and rolling stock, and are now being replaced by the $41 \frac{1}{4}-1$ b. rails.

General Considerations. - While for many obvious reasons narrowgauge lines have distinct advantages for shop work, their ability to deal with main-line traffic inwards and outwards should in every instance be carefully considered beforehand. In large engineering works where heavy weights are dealt with, it may be found economical to lay the $4 \mathrm{ft}$. $8 \frac{1}{2}$ ins. gauge, and use a special rolling stock of light and low design. The special rolling stock of $4 \mathrm{ft}$. $8 \frac{1}{2}$ ins. gauge designed for use in the arsenal will pass round curves of 75 feet radius, and is not too heavy to move by hand. Furthermore the clear space that has to be left along the centre of a shop is hardiy less for rolling stock of 18-inch gange than for that of $4 \mathrm{ft}$. $8 \frac{1}{2}$ ins. gauge, bearing in mind the width of narrow-gange 
stock that is necessary to carry a heavy load. If a narrow-gange line is adopted in large engineering works, a 2-foot or even a $2 \mathrm{ft} .6$ ins. gauge is recommended as simplifying the construction of the locomotives and rolling stock, and permitting a more effective and economical use of power; but lieut. Leggett is of opinion that in most cases it is undesirable to duplicate the gauge, where main-line traffe of $4 \mathrm{ft}$. $8 \frac{1}{2}$ ins. gauge has to be provided. The distribution of stores, such as coal, iron ore, \&c., he considers is nearly always best done by stock of $4 \mathrm{ft}$. $8 \frac{1}{2}$ ins. gauge. A saving in cartage and handling can also be effected, if goods are loaded and delivered in wagons of this main-line gauge.

\section{Discussion.}

Mr. Robertson said the immediate object in preparing this paper had been to enable the members the better to appreciate and enjoy their visit to the short experimental narrow-gauge line which many of them were to have the pleasure and privilege of inspecting tomorrow at Duffield Bank. All who availed themselves of the opportunity he was sure would appreciate Sir Arthur Heywood's kindness in inviting them to examine the many neat mechanical appliances which would be seen there in connection with the locomotives and the general design of the railway. In the remarks offered in the paper he had had in view two distinct problems in light-railway construction: the one, lines for colonial and agrieultural developments; the other, those for purely industrial purposes. The two problems were quite different, and must bo dealt with on different bases. Where the standard $4 \mathrm{ft}$. $8 \frac{1}{2}$ ins. gauge could be used, no engineer he thought would ever recommend the adoption of any other; this should be clearly understood. But there were places where funds were lacking, and where the standard gauge meant either that no line could be constructed at all and that the country could not be developed, or that years must elapse before 
(Mr. Robertson.)

any fair return could be obtained on the outlay. The question of gange nearly always depended upon that of funds and of profits. In order to raise the requisite capital, it must be shown that there was a reasonable likelihood of getting some fair return upon it. No doubt many of the members had had an opportunity in 1889 of travelling on the Decauville light railway of 60 centimetres or $23 \frac{1}{2}$ inches gauge at the Paris Exhibition. There over six million passengers had been carried without a single accident, which he thought was a great argument in favour of the utility of narrowgauge light railways when properly applied. To Mr. Chanter, and to Lieut. Leggett who was in charge of the Woolwich Arsenal railways, he wished to express his indebtedness for their lindness in furnishing the particulars appended to the paper.

He exhibited a large collection of photographs of the Darjeeling line, the Caen Dives and Luc, Sir Arthur Heywood's lines at Duffield Bank and Eaton Hall, and of some narrow-gauge locomotives.

Professor Anvold Lupton noticed that, apart from its cheapness, it had not been mentioned what the particular advantage of a narrow-gauge railway was or might be. The only advantage which occurred to himself was that it would be applicable under conditions where the curves had to be so sharp that a train could not get round them on the $4 \mathrm{ft} .8 \frac{1}{2}$ ins. gauge. On a narrow-gauge line with an overhanging weight there was less stability than where the weight was more between the rails. The speed therefore had to be reduced in going round a sharp curve. On a standard-gange line it might be impossible to scrape round a sharp curve, although it would be easy to do so on a narrow-gauge line. Moreover with regard to the question of cost, it did not seem to be shown that there was really any economy in a narrow-gauge line. Among the instances given of light railwass of $23 \frac{1}{2}$ inches gauge, that at Pithiviers in France cost $£ 1,550$ a mile, while that at Festiniog cost $£ 10,720$ a mile, or seven times as much as the other, though both were of the same gauge. This seemed to show that the element of gauge had but little to do with the cost. On the other hand he believed there were hundreds 
of miles of contractors' lines of $4 \mathrm{ft}$. $8 \frac{1}{2}$ ins. gauge which had been laid down in this country at a cost considerably under $£ 2,000$ a mile. When a main railway was going to be made, a contractor's line was first laid down, which in many instances was superior to a light narrow-gauge railway, and in some instances served as a permanent line. The contractor's line enabled a good locomotive to run all over its entire length, up and down steep gradients, and at a fair speed, taking heavy loads; and therefore he thought it remained to be shown where the advantage of narrow-gange lines came in. As a mining engineer he was not likely to ignore conditions where a narrow gauge was essential, especially underground where there was so little room. In collieries, if the wheels were put outside the wagon frame, the gauge was generally about 2 feet, though in some places it went up to 3 feet. In Table 1, giving the loads hauled by one horse, he would suggest altering the word "tramway" to "railway"; for there was daily evidence that it was not true that a horse could draw on a level $16 \cdot 7$ units of $1,320 \mathrm{lbs}$. on a tramway, while it could draw only $3 \cdot 3$ units on a metalled road; because for many years the much abused omnibus had been successfully competing with the much vaunted tramcar, and the omnibus horses got along as quickly and took nearly as many passengers as the tramcar horses, having due regard to the size and strength of the horses. While not wishing to throw any doubt upon the fact that there were places where a narrow-gauge railway might have some advantages, all he desired was to have the reasons for those advantages set forth clearly.

Mr. Mark Robinson considered that in laying down these little railways in industrial and engineering works there was no occasion for the old battle of the gauges to be fought over again. In the new engineering works of his own firm at Rugby, as in many others, it was desired to move things of considerable size about the works, such as engines or pieces of machinery weighing several tons, which nevertheless could be carried by trucks much smaller than the ordinary railway trucks. A 3-foot or even a $2 \mathrm{ft} .6$ ins. gauge was quite wide enough for such purposes. Independently 
(Mr. Mark Robinson,)

of this requirement it was also necessary to move far smaller things about upon little trucks, such as one man could easily handle. For the latter purpose either an 18-inch or a 15-inch gauge would be amply suficient, though it wonld be quite inadequate for carrying weights of several tons. On the other hand a gauge of say 2 ft. 6 ins. would give trucks far too heavy for easy handling. To meet the two sets of requirements, having already the standard gauge laid down in the works, all they had done had been to lay on the same sleepers two intermediate rails, between those of the $4 \mathrm{ft} .8 \frac{1}{2}$ ins. gauge, dividing it into three equal parts. They then had one set of trucks for carrying things on a gauge rather more than 3 feet, and another set for a gauge slightly under 18 inches. In engineering works it was highly desirable to have small-gauge lines; and the example mentioned gave a ready clue, he thought, to the best gauge to fix upon. Neither the $4 \mathrm{ft}$. $8 \frac{1}{2}$ ins. gauge nor the 3-foot gauge went all over the works, but the smallest gauge went almost everywhere. It was some practical convenience that in most places the trucks had a choice of rails to run upon: where all the gauges ran together, there were three tracks on which the smallest trucks, and two on which the 3 -foot trucks, might run.

Mr. Charlfes Wioksteed thought one aspect of narrow-gauge railways which had not been mentioned in the paper was of some importance, namely their applicability to tourist lines. It would generally be noticed that, the cheaper the line, the prettier was the ride. The reason was not because it happened to be a cheaper line, but because being a narrow-gauge railway it went round curves, instead of going through cuttings and tunnels. Narrow-gauge railways wound round the hills, and a beautiful view of the country was obtained everywhere. A great deal more might in his opinion be done in that way. In all frequented tourist districts there would be noticed dusty roads and troops of visitors riding in carriages behind overworked horses. It would be a great improvement he thought if those dusty roads and panting horses were replaced throughont the country by convenient little narrow-gauge railways and locomotives. The valleys would not then be blocked with huge 
embankments, for there would be no necessity for going to the expense of making any. Passengers who had travelled on the Festiniog Railway and other light railways in Wales must have admired the beautiful scenery, not because these lines went through a more beautiful country than the larger and better lines, but becauso they wound round about on the open hillsides, instead of going through cuttings and tunnels.

Mr. R. R. Lister said his experience had been entirely confined to railways in industrial works, particularly those in Messrs. Beyer Peacock and Co.'s works at Gorton, Manchester, where there were railways of 18 inches gauge extending throughout the yards and shops. There curves of 13 feet radius had been introduced, on which were worked four-wheel coupled locomotives; the latter had the advantage of utilising all their weight for adhesion, so that they were able to haul loads of considerable weight. The trucks carried as much as 4 tons each, and were used not only singly, but also coupled two or three together, and by the use of swivelling bolsters long articles such as locomotive frames could be transported on them. In that way a large number of labourers had been dispensed with, and also three horses which formerly did the work of hauling. Their experience went to prove that the plan was of great advantage.

Mr. H. J. Butren, having had a large share in the responsibility of introducing the railway of 18 inches gauge into the Royal Arsenal at Woolwich, said that the great object in view had been to obtain a railway which would enable material to be conveyed into the shops and through them. The narrow-gauge railway had enabled this object to be accomplished by turning round sharp curves. The wider standard gauge of $4 \mathrm{ft}$. $8 \frac{1}{2}$ ins. would not admit of going from one shop to another, or from one part of a shop to another part; but the adoption of sharp curves in conjunction with the 18-inch gauge enabled material to be conveyed expeditiously and economically throughout the whole of the works. It was now nearly thirty years since the narrow gauge had been introduced into 
(Mr. H. J. Butter.)

the arsenal, and it had been working successfully ever since, carrying heavy loads through contracted spaces.

Mr. Jeremtah Head, Past-President, thought that, in advocating narrow-gauge light railways, the author had hardly taken credit enough for the great advantages which the use of sharp curves afforded in a mountainous country. If the gauge and rolling stock were adapted to quick curves and heavy gradients, it was quite clear that railways could be made under many difficult conditions occurring in nature, such as winding up the valleys of rocky rivers, and ascending spirally inside mountains up to the summits. There were numerous instances where narrow-gauge light railways could be made in mountainous districts, which would not be accessible to standard-gauge tracks without exceedingly heavy works. Having travelled on most of the light railways referred to in the paper, and particularly on the Decauville railway at the Paris Exhibition of 1889 , he had found it somewhat startling, when rounding a quick curve and sitting in the back part of the train, to see the engine going at right angles to the tail end of the train. To those accustomed to ride in ordinary standard-gauge trains, such an experience was quite a novel one. The rolling stock should all be on bogies, if the plan were to be carried out properly. The introduction of bogie rolling stock was attended with highly satisfactory results on the ordinary standard gauge; and it was particularly applicable and necessary if the full advantage was to be obtained of narrow-gauge railways, because trucks or cars of good size could then be made, which would go round almost any curve. The bogie system was far more extensively used in the United States than in England, for the Americans were quick in taking advantage of anything which would save money and labour. On the principal railroads in America all except the standard gauge had been abandoned, except in mountainous regions where some narrowgauge railroads were still in use. The tendency of experience everywhere was to make rails heavier. In the course of the paper it had been shown that in several instances the weight of the rails had been increased. This was partly due to the fact that with 
light rails it was found difficult to maintain the joints. By increasing the weight of the rails it was evident that stiffness at the joints was increased in much greater proportion than was due to the extra weight of rail. This subject had been dwelt upon by Mr. Johnson in the excellent Presidential address he read at the last meeting (Proceedings, April 1898, pages 168-9). He entirely agreed with the author that there was abundant use for narrowgauge railways in and about works, or as isolated railways for long distances in new countries and colonies, where the full price of the standard gauge could not be afforded; and particularly in mountainous regions, where heavy works could not be paid for, and where the only alternative was to wind round mountains and follow the bends of rivers.

Mr. Whilam H. Maw, Vice-President, said one reason for the use of narrow-gauge railways had not been alluded to; which to some extent met Professor Lupton's enquiry (page 390): namely that with the reduction of the gauge a material reduction was obtained in the size of the working unit. On the ordinary $4 \mathrm{ft}$. $8 \frac{1}{2}$ ins. gauge, trucks could not well be used weighing less than $4 \frac{1}{2}$ or $4 \frac{3}{4}$ tons each, and carrying a load less than their weight or one-and-a-half times their weight. Coming down to the narrow-gauge railways referred to in the paper, it was seen that the trucks weighed only from 8 cwts. to $10 \mathrm{cwts}$. each, and carried about a ton load. Such trucks were much more convenient to handle at small roadside stations and in places where there were not facilities for shunting heavier trucks; this he thought was an important advantage. The best size and weight for the working unit would vary roughly as the cube of the gauge: for a gauge half the width of the standard gauge, the cubic capacity and weight of the trucks would be about one-eighth of the ordinary standard trucks. With regard to speed, it might be interesting to know that on the Festiniog Railway high speeds had been attained. Some twenty-four or twenty-five years ago he had happened to have facilities for making many runs on that line, and the speed had on several occasions reached the rate of 48 miles an hour without the least trouble; the engines ran 
(Mr. William H. Maw.)

perfectly steady, and went round sharp curves without any inconvenience whatever. The curves were all parabolic, and carefully laid; and the road was good right through.

Mr. Thomas Daniers considered the 18-inch gauge, adopted for the narrow-gauge railways in Woolwich Arsenal, and in the large works of Messrs. Beyer, Peacock and Co. and other works in the country, was all that was required for the purpose. It was impossible to lay a line of wider gauge into the works for conveying articles about with facility. Whenever it was desired to increase the output, another shop would be built and the same gauge laid into it. Dockyards, breweries, and steelworks, having gauges of 2 feet or $2 \mathrm{ft} .6$ ins., would be dealt with in the same way, in accordance with their respective gauges. At the Bridgewater Foundry, Patricroft, he had made a good many narrow-gauge engines, some to run on a single central rail, but mostly to run on two; they varied in weight from about 3 tons up to 18 tons. The Darjeeling Railway referred to in page 379 was giving good results, as shown by the author. In a letter received recently from the locomotive superintendent it was stated that the weight of the locomotives would have to be increased still further. The railway had been made about twenty years ago, and the locomotives were now required to be about 50 per cent. heavier than they were then, namely 18 tons instead of 12 tons. It was one of the most successful mountain railways; but now the traffic had developed to such an extent that it would have been better if a wider gauge had been adopted, as it was diflicult for an 18-ton engine to be worked in on a 2-foot gauge. As far as could be foreseen the line would go on prospering and would carry still further traffic, because it was leading out into the Assam tea-gardens, where locomotives would be required. One great mistake apt to be committed when a country decided to make railways was that foo much importance was attached to the question whether they were going to pay immediately. In the colonies he considered it would be a great mistake to adopt any narrower gauge than the English standard. During the last ten or twelve years a large number of locomotives had been made in this country for the railways of $3 \mathrm{ft} .6$ ins. gauge in Japan. The Japanese 
were already beginning to enquire what it would cost to convert their narrow gauge into the standard $4 \mathrm{ft}$. $8 \frac{1}{2}$ ins. gauge, which if it had been originally adopted would have allowed for the increase in the trade of the nation. It would therefore be a great mistake he thought if the leading engineers who were being consulted with regard to the railways in China did not press the Chinese to adopt the $4 \mathrm{ft}$. $8 \frac{1}{2}$ ins. gauge; otherwise the Russian 5-foot gauge would overrun the northern part of the country to Pekin, and would control that sphere of commercial interest. A narrow gauge was right enough for industrial works, such as coal mines and dock-yards; but for a nation that was going to embark largely in trade, anything less than the $4 \mathrm{ft} .8 \frac{1}{2}$ ins. gauge would be a great mistake. In Great Britain the leading locomotive engineers would be glad indeed if the railways were 5 feet gauge, instead of $4 \mathrm{ft}$. $8 \frac{1}{2}$ ins. For our own light railways it was worth while to consider the desirability of adopting in any district the same gauge as that of the local tramways, because the latter could then be utilised for bringing farm and garden produce to market in the intervals of the passenger traffic. If the tramway gauge was not too broad for the principal streets in the towns, it ought not to be so for the turnpike roads in the country. In order to see for himself, he had recently travelled on the light railway of ordinary tramway gauge from Wolverton to Stony Stratford; it was laid along the opposite side of the road to the footpath, the hedges and ditches being trimmed up; the road was an average cross-country turnpike road, and there was plenty of room left for the ordinary vehicles; and he did not see any reason why this gauge of light railway could not be generally adopted.

Mr. Arthdr Kene, Vice-President, thought it was clear from the paper that, if a narrow-gauge railway were laid down, the cost would under some circumstances be only about one-third of that of a standard-gange line, which in some instances therefore would probably never be laid down at all. Narrow-gauge railways he thought were quite suitable for a good many districts and for a good many purposes; it seemed to him there was much to be said in their favour, and little against them. If it were to be understood 
(Mr. Arthur Kieen.)

that only railways of $4 \mathrm{ft}$. $8 \frac{1}{2}$ ins. gauge were to be adopted, then the purposes of the light-railway act would at once fall through. In that act it was the intention of the government to put light railways where standard-gauge railways would never be put on account of their much heavier expense. He was glad this subject had been brought before the Institution in the present paper, for he was sure it would result in great advantage to the country generally.

Mr. Michael Longridge said that about thirty years ago he had been employed on the metre-gauge railway over Mont Cenis; and his experience there had led him to devote his attention to the design of locomotives for narrow-gange railways. The difficulty was to get boiler power enough on a sufficiently short wheel-base, without excessive loads upon the wheels. This difficulty was materially increased by reducing the gauge; and in his opinion therefore it was better to spend a little more in adopting the standard $4 \mathrm{ft} .8 \frac{1}{2}$ ins. gauge, and by heavier gradients to compensate for the extra cost of the flatter curves which this gauge required, in preference to reducing the gauge and using a toy locomotive which would draw but little after it. The problem for mechanical engineers in connection with light railways seemed to him to be the production of a locomotive which would drag a heavy load upon light rails and round sharp curves. Many years ago his father and himself had jointly designed such an engine, in which the boiler was to contrin 2,500 square feet of heating surface, and was to be carried on three bogie trucks. The cylinders, which were vertical, were to be connected rigidly with the boiler and with a dead axle sliding vertically in horn blocks between the two other axles of the middle bogie truck. Each of the other bogie trucks was to have three axles. The wheels of each truck would have had a rigid wheel-base of 8 feet, and were to be coupled together by outside coupling rods; while the trucks themselves were to be coupled together by spur wheels, arranged in such a way as to retain their proper relative positions when the axles radiated in passing round the curves. The engine would have weighed 72 tons, with $4 \frac{1}{2}$ tons on each of the sixteen wheels; and would have drawn 130 tons up a gradient of 1 in 15 and round a 
curve of 90 feet radius. The use of $\operatorname{cog}$ wheels in a locomotive would no doubt seem inadmissible to many; but his experience on the Mont Cenis Railway had led him to think that, for the slow speeds which would suffice on most light railways, they would work satisfactorily. For the gearing, steel castings were at first intended to be employed, but cast-iron was found at that time to be more reliable; at the present time the reverse was the case. To those who were contemplating the design of heavy locomotives for light railways he had no hesitation in recommending that they should consider carefully the question of adopting spur gearing.

Mr. W. Stemue Tomkins thought that, without fighting over again the battle of the gauges which had been fought out so many years ago, surely the gauge question was merely one of proportion. The justification given in the paper for light narrow-gauge railways was that they were a means to an end. Anyone who had a bushel of potatoes to carry would not send for a trolley with two horses, but for a wheelbarrow; whereas for carrying a load of coals he would send for a trolley with two horses and not for a wheelbarrow. Having himself had something to do with encountering the difficulty experienced in providing steam enough, he could say that the Darjeeling engines were so built that they made plenty of steam. That line had become an example for the rest of India, where the narrow-gauge plan was being developed to a large extent, and was likely to become highly useful. It was already doing a good deal of work, and would probably do a great deal more.

Mr. Bryan Donin, Member of Council, hoped that, as there seemed to be a large field for narrow-gange lines, the author could give some more details with regard to the small locomotives, their consumption of fuel and water, and any definite experiments that might have been carried out. No mention had yet been made of the kind of fuel used, or the amount of water, or the indicated horse-power, or the traction pull. If a few details on these points could be given, they would enable a better comparison to be drawn between narrow-gauge railways and those of standard gauge. 
Mr. Robertson agreed that cheapness was the principal and fundamental reason for the adoption of light railways (page 390). There were other obvious reasons however, such as the greater facilities of alignment, the use of sharper curves, and the reduced tare of wagons compared with the load hauled. All engineers he thought who had had any experience in the practical working of light railways would have seen reasons for their adoption. As to the argument that, while the Pithiviers line cost only $£ 1,550$ per mile, the Festiniog cost as much as $£ 10,720$ per mile, he had purposely given the latter particular instance, because it showed that even with so expensive a line it was quite possible to earn a good dividend; whence it might reasonably be expected that lines involving much smaller outlay would also make a good return.

The practical utility of these narrow-gange lines in engineering works had been exemplified by Mr. Mark Robinson (page 391); and it might further be pointed out that they were not meant to supplant but to supplement the standard-gauge lines in works. Further practical proofs of their utility were furnished (page 393) in the remarks of Mr. Lister and Mr. Butter.

One great reason for the adoption of narrow-gauge railways was that given by Mr. Wicksteed (page 392), namely that the contour of the country could be followed by light lines, without expensive embankments, cuttings, and tunnels, which could not be done by the heavier lines. A great deal of the difference in the cost was due to this reason.

With Mr. Head's appreciation of bogie stock for light railways (page 394) he entirely concurred; there was no doubt the bogie system was the right one for all passenger traffic, and also for goods traffic, except where the loads to be carried were very small and wagons of small size had to be adopted. Certainly there was no doubt that the rails in most instances had been originally laid down too light (page 394). It would be noticed that the renewals mentioned in the paper had always been made with a heavier section than had originally been adopted.

A certain difficulty might have been met with in regard to the boiler power (page 398); but he thought no one who had seen the 
locomotives which had been shown at Leeds by Mr. Calthrop for the Barsi light railway of $2 \mathrm{ft}$. 6 ins. gange would be much troubled on that score. The curious locomotive weighing 72 tons, devised by Mr. Longridge, he thought could hardly be looked upon as a practical solution of the difficulty. It was only when the gauge was Fery narrow indeed that the boiler power was a difficulty.

Sir Arthur Heywood's line, which a number of the members would have the pleasure of seeing at Duffield Bank, was intended only as a model ; they were therefore asked to look upon it in that light. It had been made as an experimental line, pure and simple; and those who were looking for a solution of the mechanical problems occurring in light-railway design would see that Sir Arthur had solved some of them in a highly workmanlike way. At the present time, when there were no less than five or six different narrow gauges before the Light-Railway Commission, he thought the members of this Institution ought to have a voice in the adoption of one standard narrow gauge, or of two at the most, if the $4 \mathrm{ft}$. $8 \frac{1}{2}$ ins. gauge had to be departed from. Where the $4 \mathrm{ft}$. $8 \frac{1}{2}$ ins. gauge could be adopted, no one would hesitate to adopt it; but if it had to be departed from, he thought something might advantageously be done to stop the indiscriminato laying down of any gauge which any engineer might see fit to put forward.

The Prestdenx proposed a hearty vote of thanks to Mr. Robertson for his paper.

Mr. W. G. BaGNaLL, Stafford, wrote that from his experience in making a large number of locomotives of 2 feet gauge and under ho was unable to agree that it was desirable to have more than four wheels (page 382); a single illustration could hardly be accepted as conclusive in favour of six wheels, because a good deal depended upon the construction of the road and the balancing of the engine. Neither could he agree that light-railway locomotives had a greater tractive power in proportion to their gauge than standard-gauge locomotives (page 383); because there was no doubt that friction was greater on 
(Mr. W. G. Bagnall.)

narrower gauges than on standard gauge. In page 387 it was said that tank engines with a trailing bogie, built by his firm, were found to be rather apt to ieave the rails, the bogie arrangement not being entirely satisfactory for the work. Here however another bogie had been preferred to that which he had proposed to supply; it was a new design, and had at that time been thought by the authorities to be an improvement. Bagnall's Ajax engines, also mentioned in page 388 , had been built specially for the War Office from his own designs, with the exception of one or two brasses which had been made duplicates of those in other engines running there.

Mr. H. Beranr Graham wrote that he was informed by the engineer of the Darjeeling Railway that the capital cost of about $\mathfrak{\$ 4 , 0 0 0}$ per mile (page 380 ) was no doubt approximately correct, if it was understood to represent only the cost of construction of the permanent way and rolling stock and the cost of strengthening the previously existing bridges. But this line had been rendered possible at so low a cost per mile by the concessions obtained from the Bengal government, whereby the railway secured absolute rights to the already existing road, free land for stations and diversions, and immunity from initial expense for preliminary surveys, which would have cost about $£ 1,000$ per mile. The roadway up to the military hill station had been constructed by the government many years previously at a great cost, and many proposals had been considered for laying a tramway up it, leaving it still serviceable for bullock traffic; but subsequently it had been made over absolutely to the railway, in consideration of the government receiving a division of the profits after a stated dividend per annum had been declared. The gauge was mentioned as $23 \frac{1}{2}$ inches (60 centimetres) alike on the Darjeeling, the Pithiviers, the Caen, the Festiniog, and the French and German military lines; but on the Darjeeling Railway he was informed that the actual gauge laid down with the 30-lb. rails was exactly 2 feet.

Mr. H. Cripps Mathmson wrote that just beyond the limit mentioned in the title of the paper the Egyptian Delta Light 
Railways were at the present time being laid out in the provinces of Beherah and Gharbieh in Lower Egypt on a gauge of 75 centimetres or $29 \frac{1}{2}$ inches. The lines ran chiefly along one side of the public roads, supplemented by occasional diversions through adjoining land to avoid awkward corners. The grounds on which this gauge had been selected by Messrs. John Birch and Co., who had obtained the concession, were-firstly, that it was adequate to carry all the traffic expected; secondly, that it rendered the lines much less costly in themselves than if of standard gauge; thirdly, that by permitting much sharper curves to be used than on the standard gauge it enabled the lines to be constructed with the minimum requirements for land at corners of roads, and involved minimum interference with land boundaries; and fourthly, that it was suitable for the construction of branch lines into villages or estates, or temporarily into fields for crops. The country was flat, populous, and generally fertile or capable of becoming so whenever water could be brought upon it; but hitherto poorly provided with means of transport, except the main lines of standard gange, to which these new lines would be feeders in addition to having their own local traffic. A resident of long experience in the country had written, under date 18 June 1898, that there were about 37 miles open, and the trains were larg ly patronised; and that these railways would revolutionise travelling in the interior of Egypt.

Mr. Robertson wrote that Mr. Graham's remarks (page 402) illustrated clearly how existing roads might advantageously be used for light-railway construction, thereby greatly reducing the capital cost of the line.

The gange of 75 centimetres or practically $2 \mathrm{ft}$. 6 ins., selected for the Egyptian Delta Light Railways as mentioned by Mr. Matheson (page 403), was one of the best, he considered, if not the very best, for light railways of any considerable length.

The two views of the Duffield Bank Railway shown in Plate 79 were from photographs taken by Mr. C. F. Budenberg during the visit of the members to Duffield Bank. 


\section{Duffield Bank Railway, 15-inch gauge.}

Locomotive No. 1. 1875.

Cyls. 4 ins. by 6 ins. Wheels 1 ft. $3 \frac{1}{2}$ ins. Weight 1 ton 3 cuts.

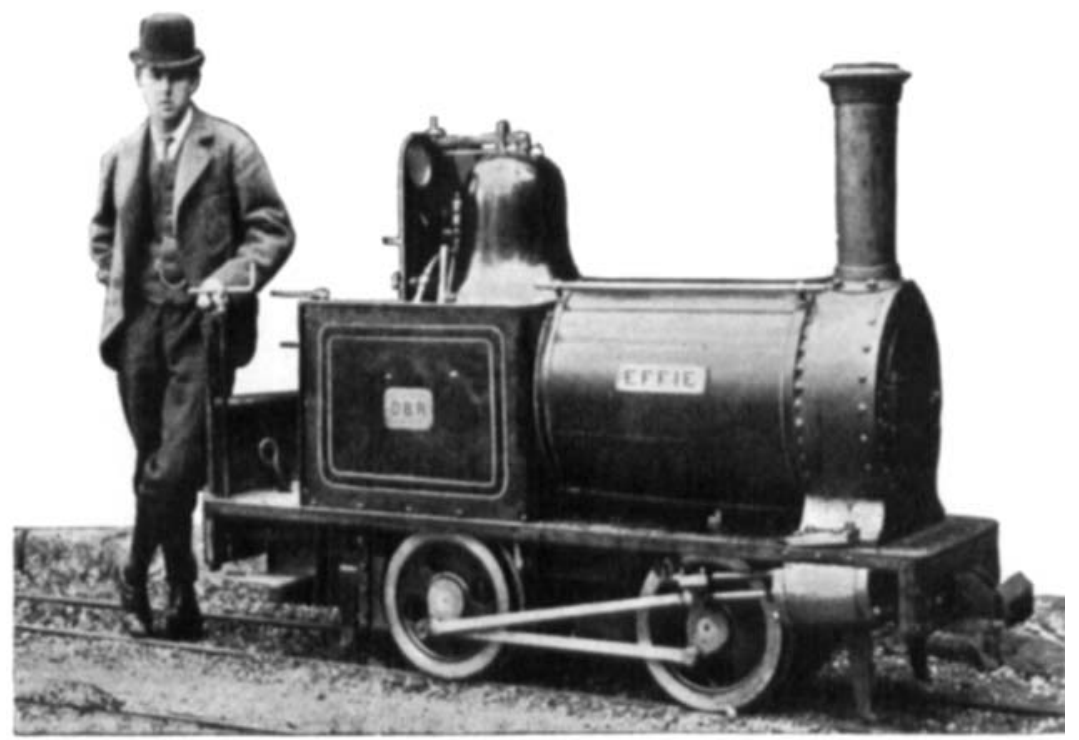

Locomotive No. 2. 1881.

Cyls. $4 \frac{7}{4}$ ins. by 7 ins. Wheels $1 \mathrm{ft} .1 \frac{1}{2}$ in. Weight $3 \frac{3}{4}$ tons.

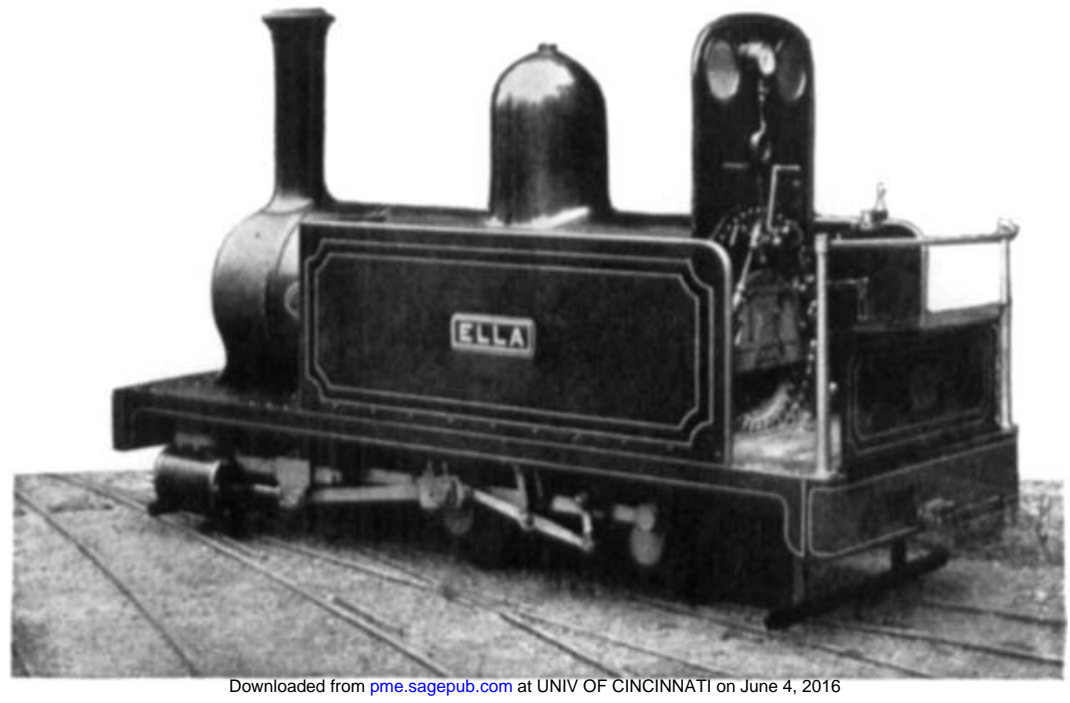


NARROW-GAUGE RAILWAYS. Plate 76.

Duffield Bank Railway, 15-inch gauge.

Locomotive No. 3.1894.

Cyls. 61 ins. by 8 ins. Wheels 1 ft. 6 ins. Weight 5 tons.

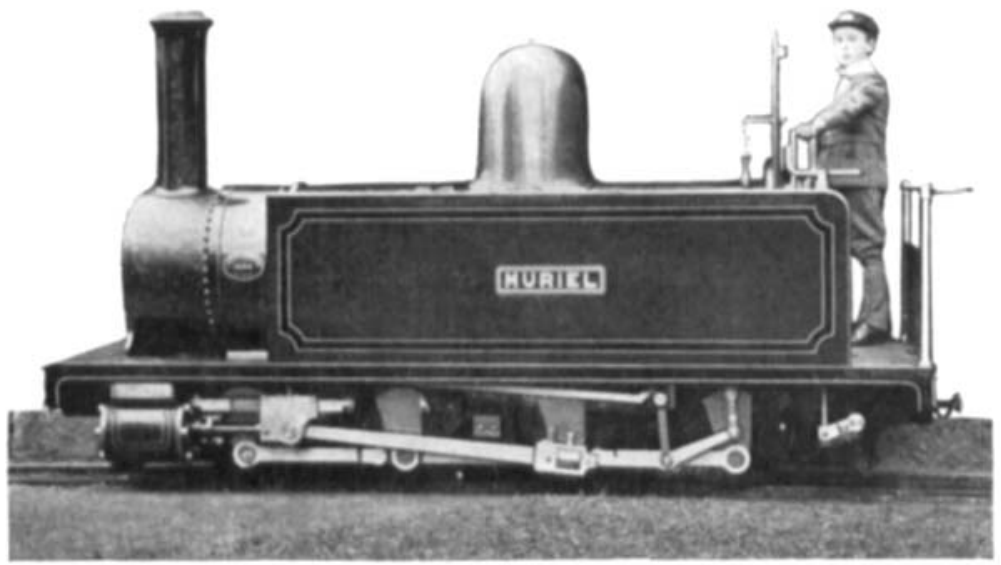

Eaton Railway, 15-inch gauge.

Locomotive No. 4. 1896.

Cvls. 15ins. by 7 ins. Whecls 1 ft. 3 ins. Weight $3 \frac{1}{4}$ tons.

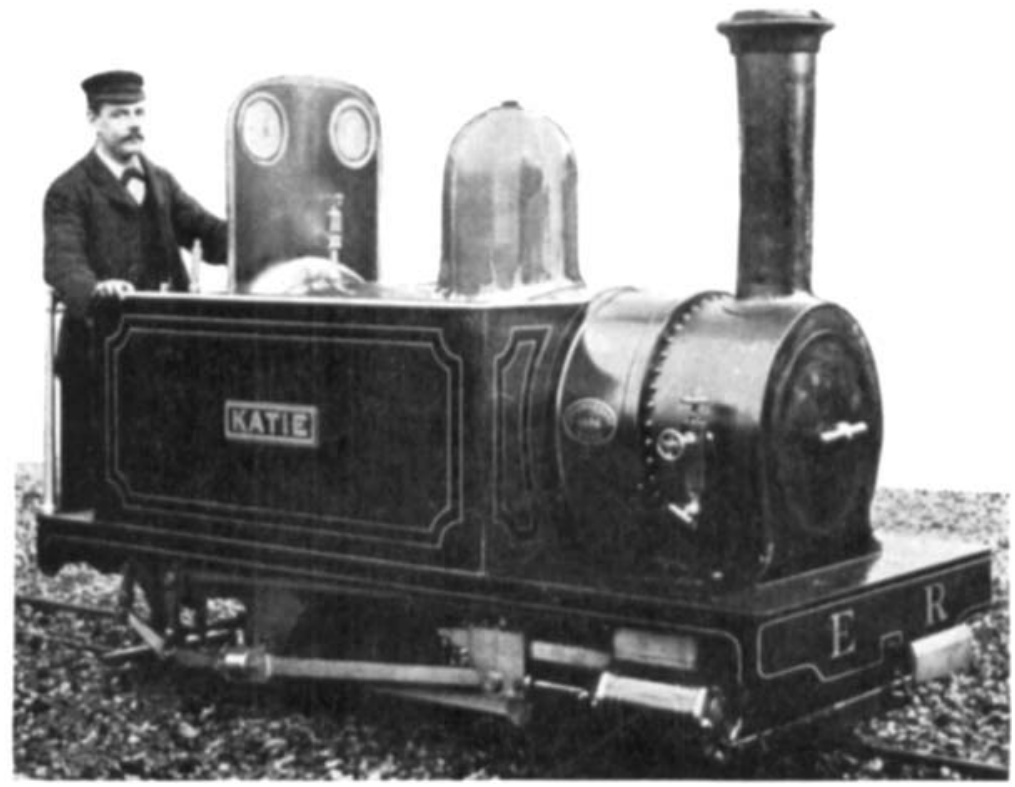

Downloaded from pme.sagepub.com at UNIV OF CINCINNATI on June 4, 2016 Mechanical Engineers 1898. 
Duffield Bank Railway, 15-inch gauge.

Plan of Radiating Gear ini No. 2 Engine.

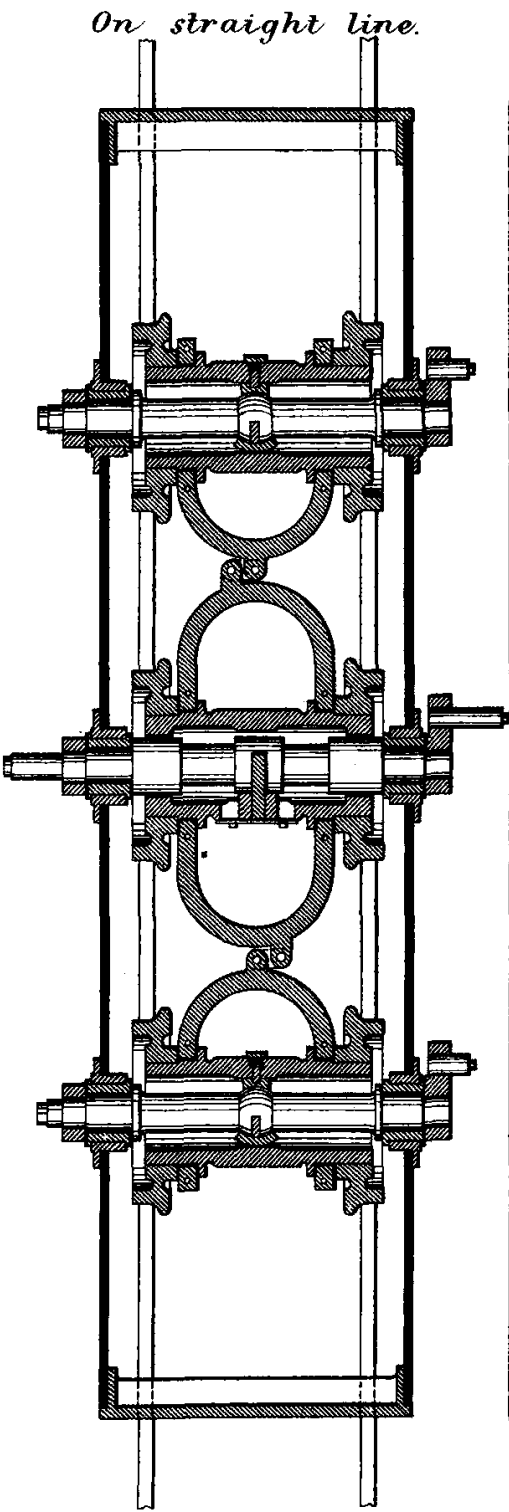

On curve of 25 feet radius.

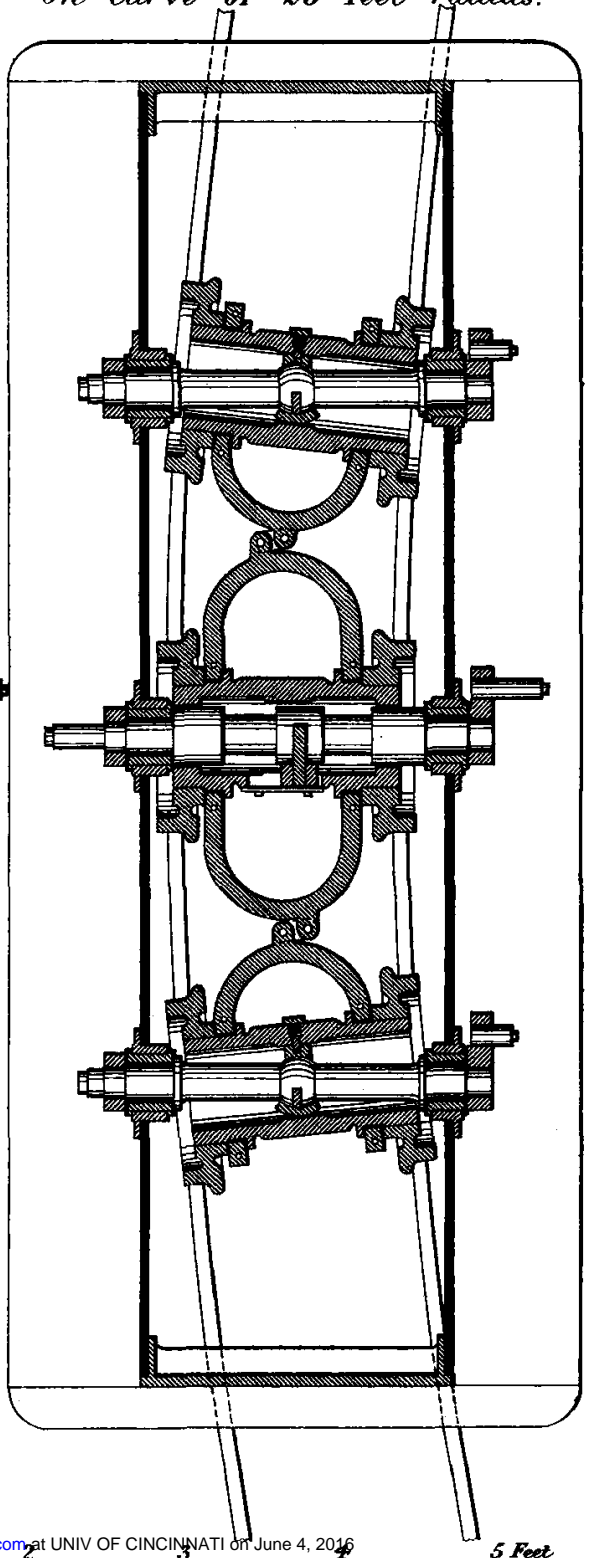

Mechanical Engineers 1898. 


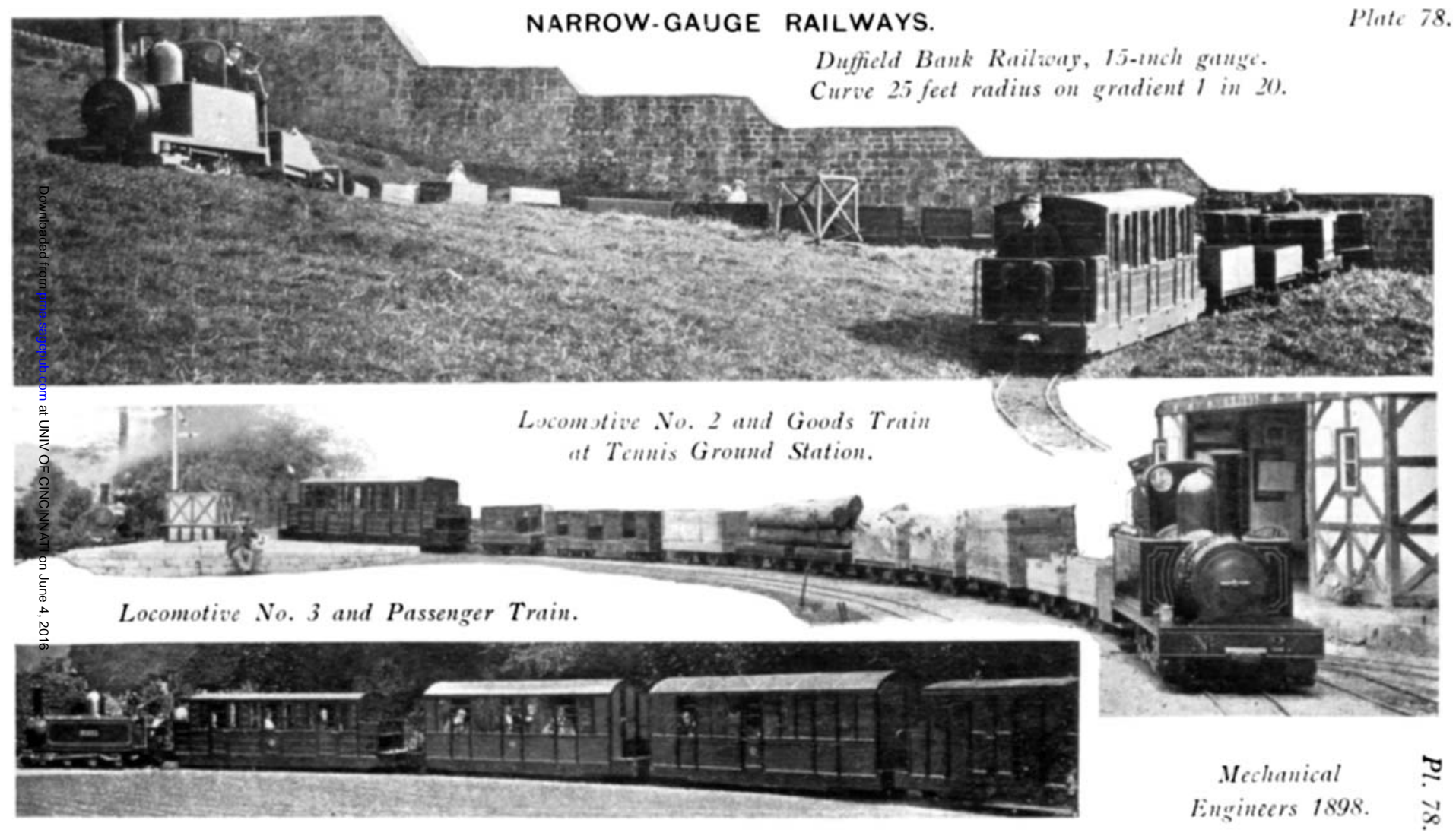


NARROW-GAUGE RAILWAYS. Plate 79.

Duffield Bank Railway, 15-inch gauge.

Signals and Tunnel.

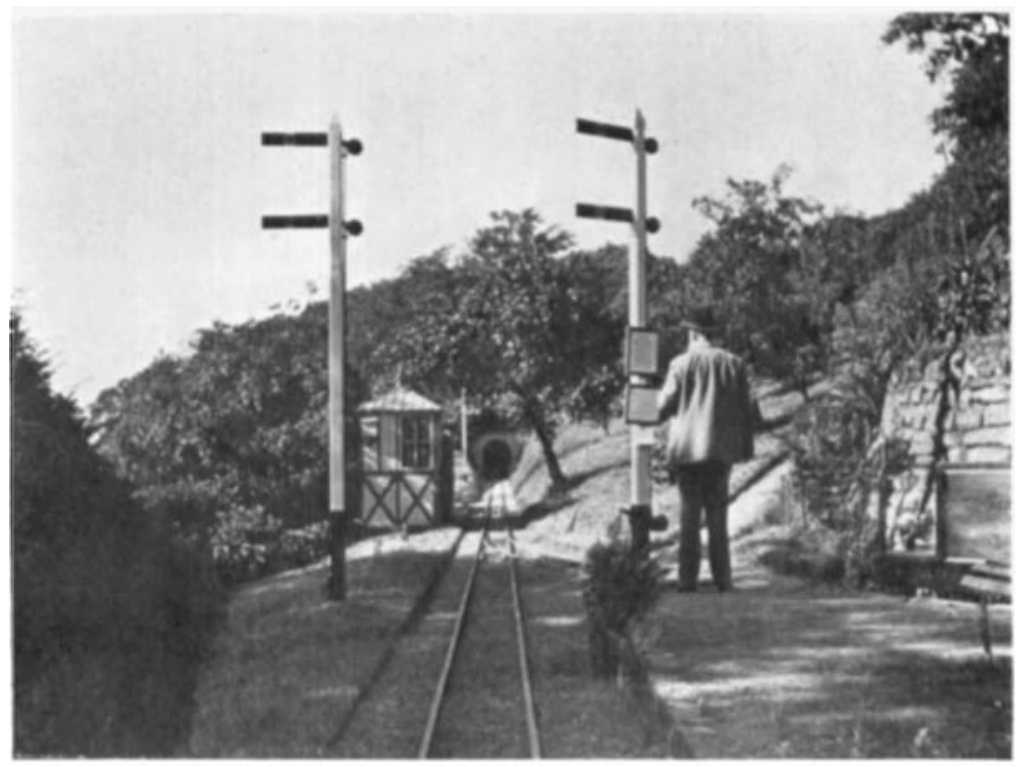

\section{Tennis Ground Station.}

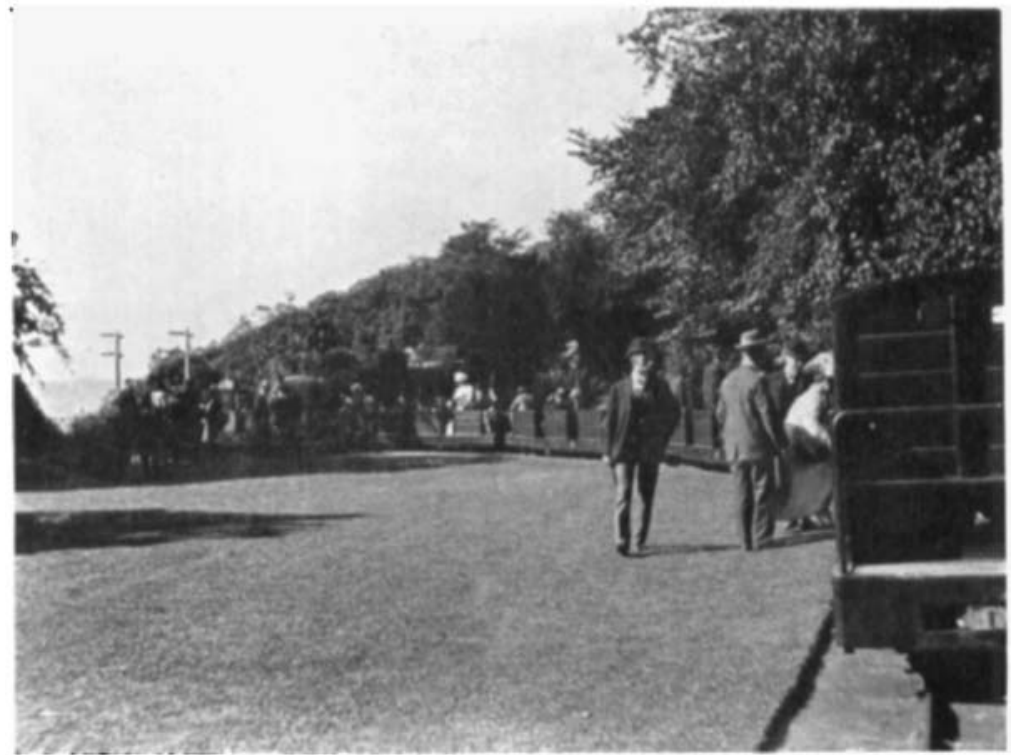

Downloaded from pme.sagepub.com at UNIV OF CINCINNATI on June 4, 2016 Mechanical Engineers 1898. 
Duffield Bank Railwoay, 15-inch gauge.

Timber Viaduct, 1878, 91 feet longr, 20 feet high.

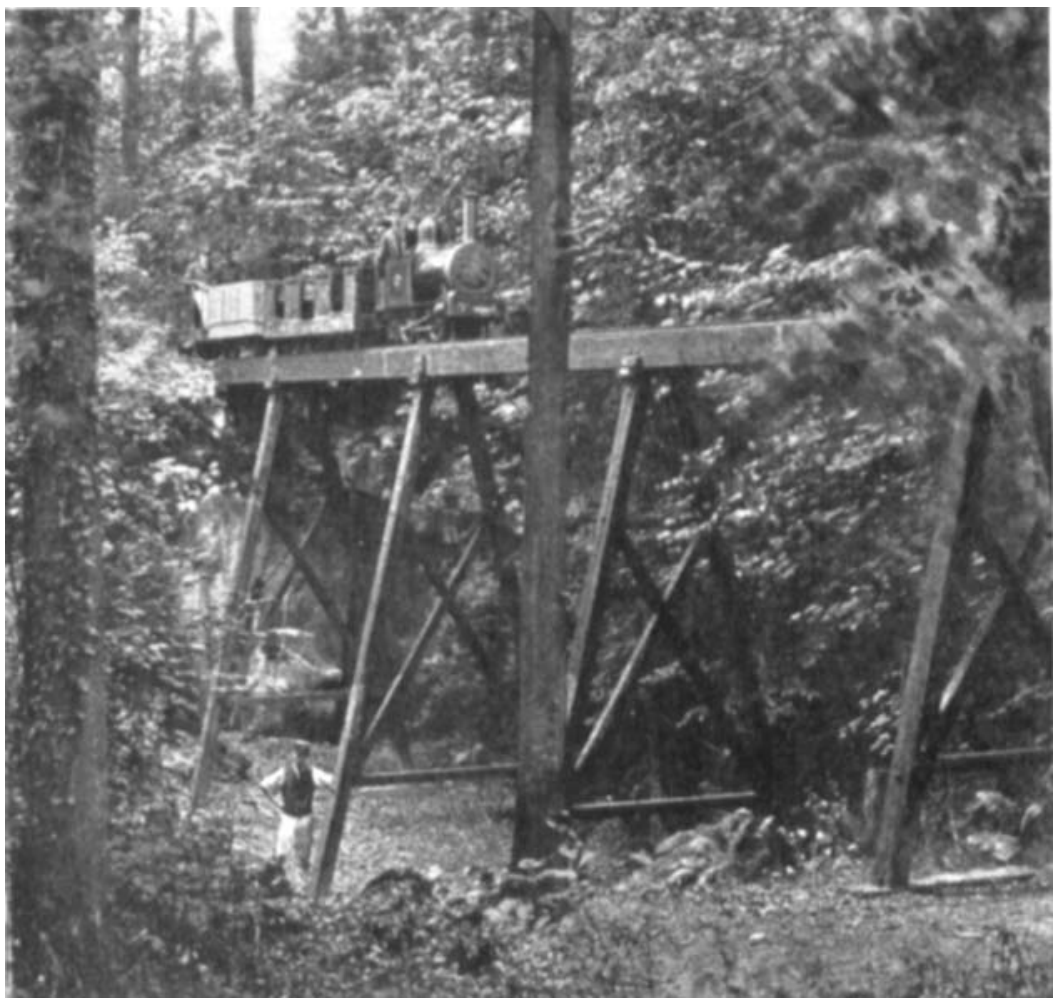

Passenger Carriage, to seat sixteen.

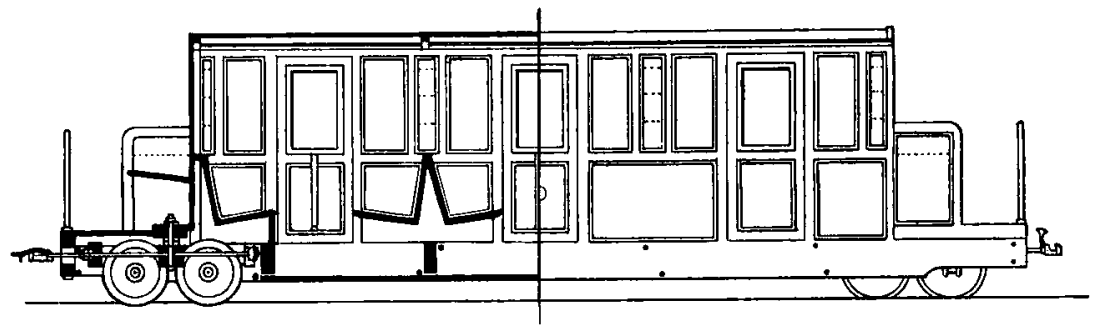

Scale $\frac{1}{6}{ }^{\circ} t h$.

ก 5 ro $\quad$ I5 $\quad$ Fcet 20 
NARROW-GAUGE RAILWAYS.

Plate 81.

liaton Railady, li-inch gauge. Balderton funtion.

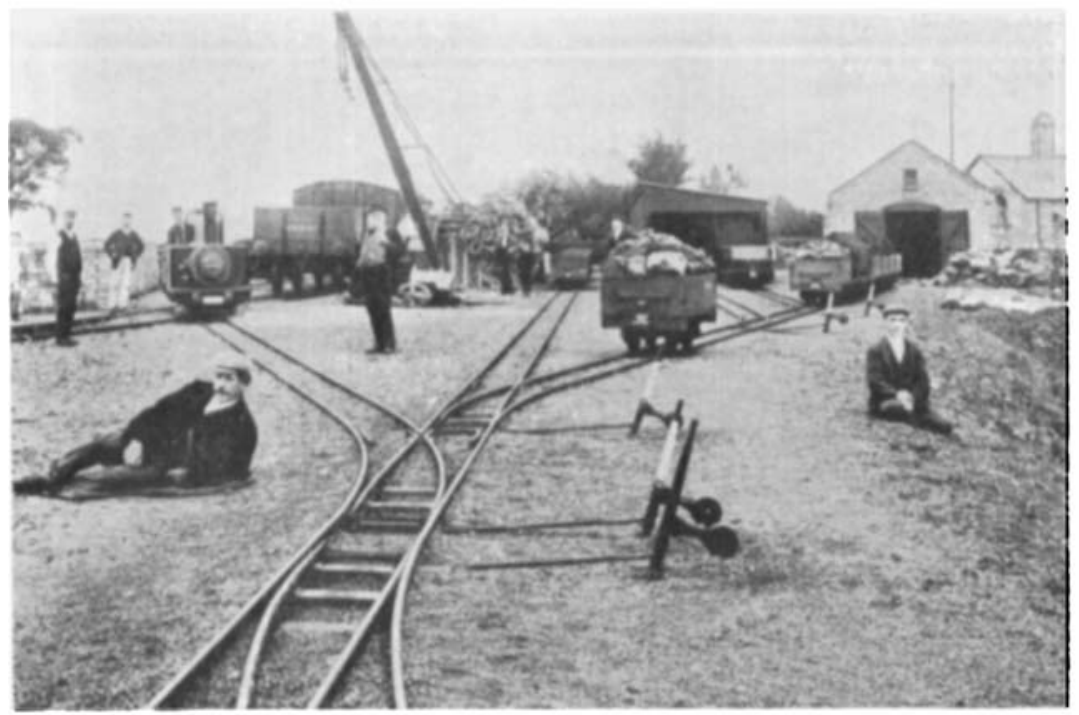

Horwich Works, 18-inch gause.

Cyls. ; ins. by 6 ins. Whecls 1 ft. It ins. Weight $3 \frac{1}{\mathrm{l}}$ tons.

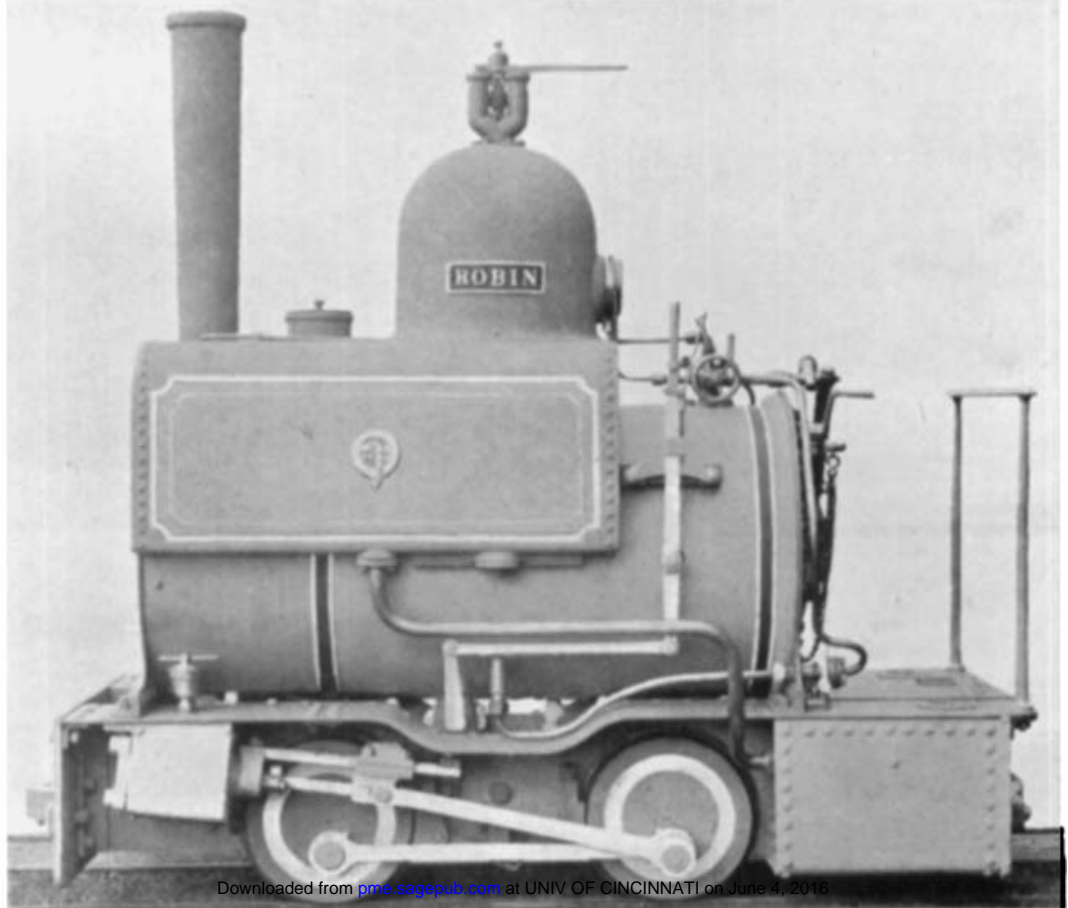

Mechanical Enginecrs 1898 . 
Caen, Dives, and Luc Railway, 23t-inch gauge.
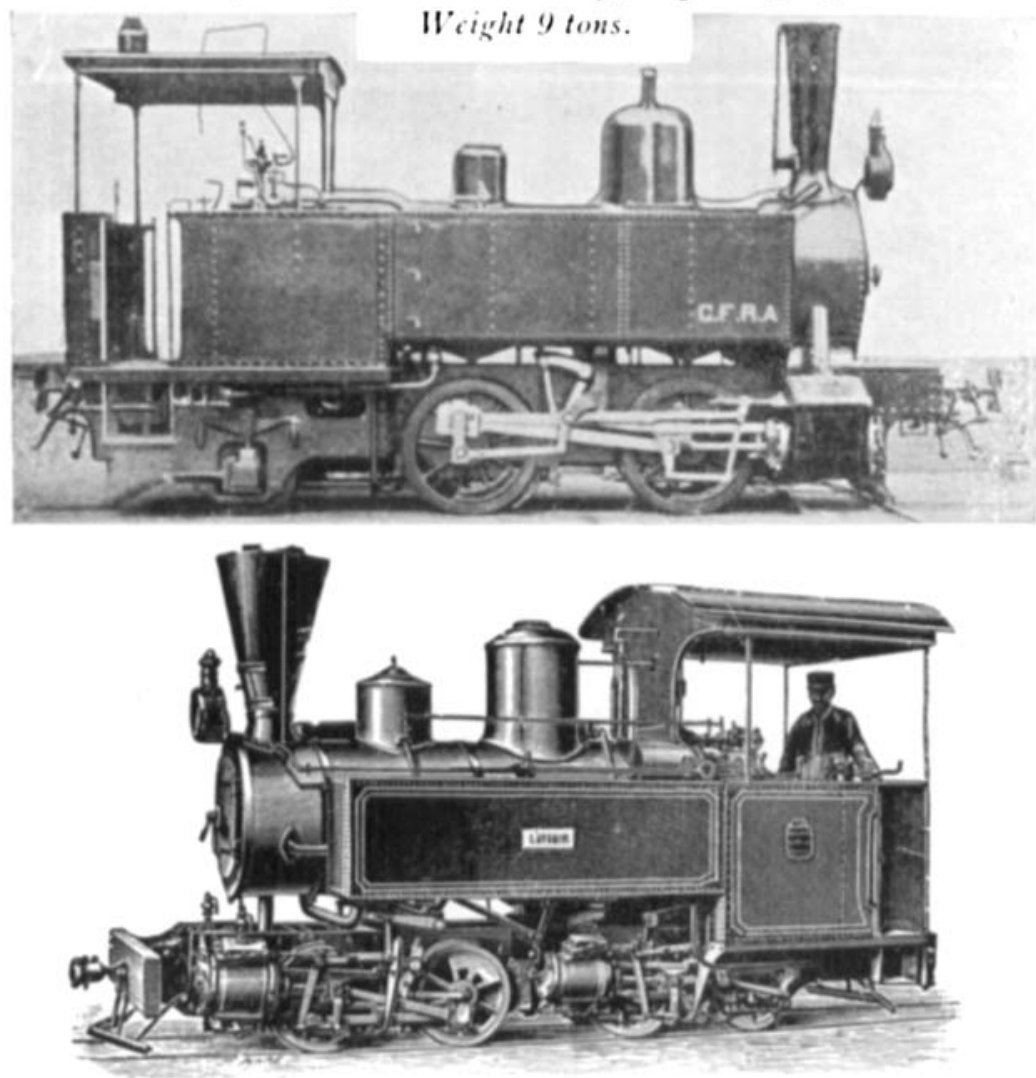

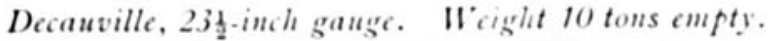

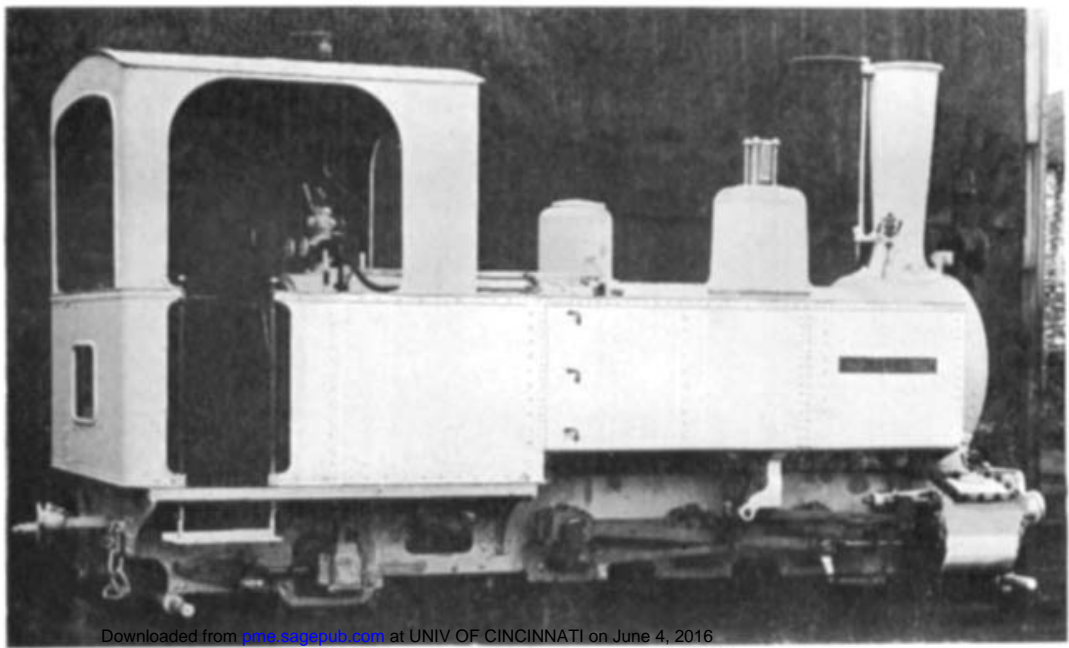


Darjecling Rinilialay, 2.foot gauge.

$$
\text { Cyls. IO ins. by } 11 \text { ins. Whecls } 2 \text { ft. 2ins. }
$$

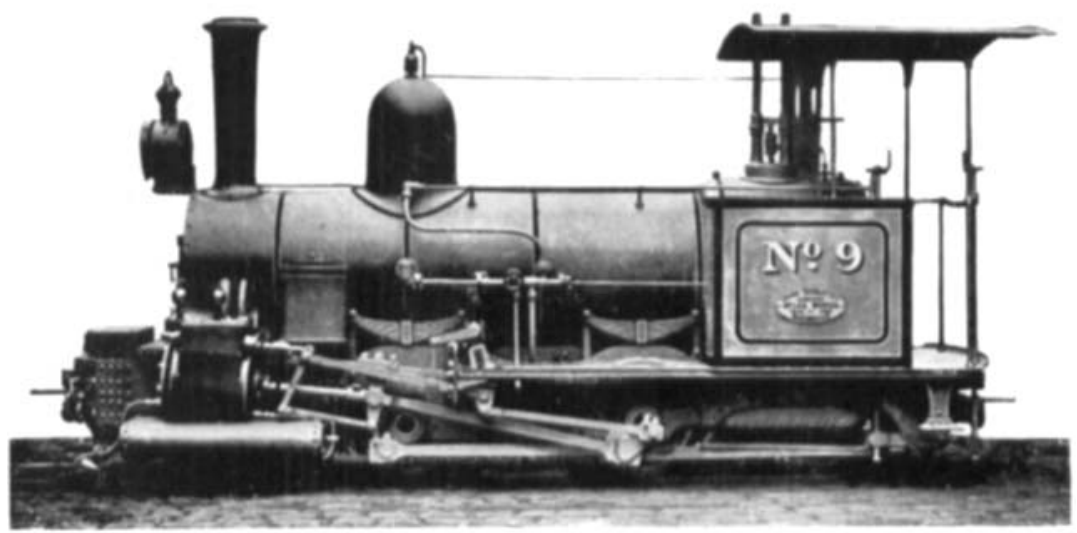

Cyls. 11 ins. by 11 ins. Whecls 2 ft. 2 ins. Weight 133 tons.

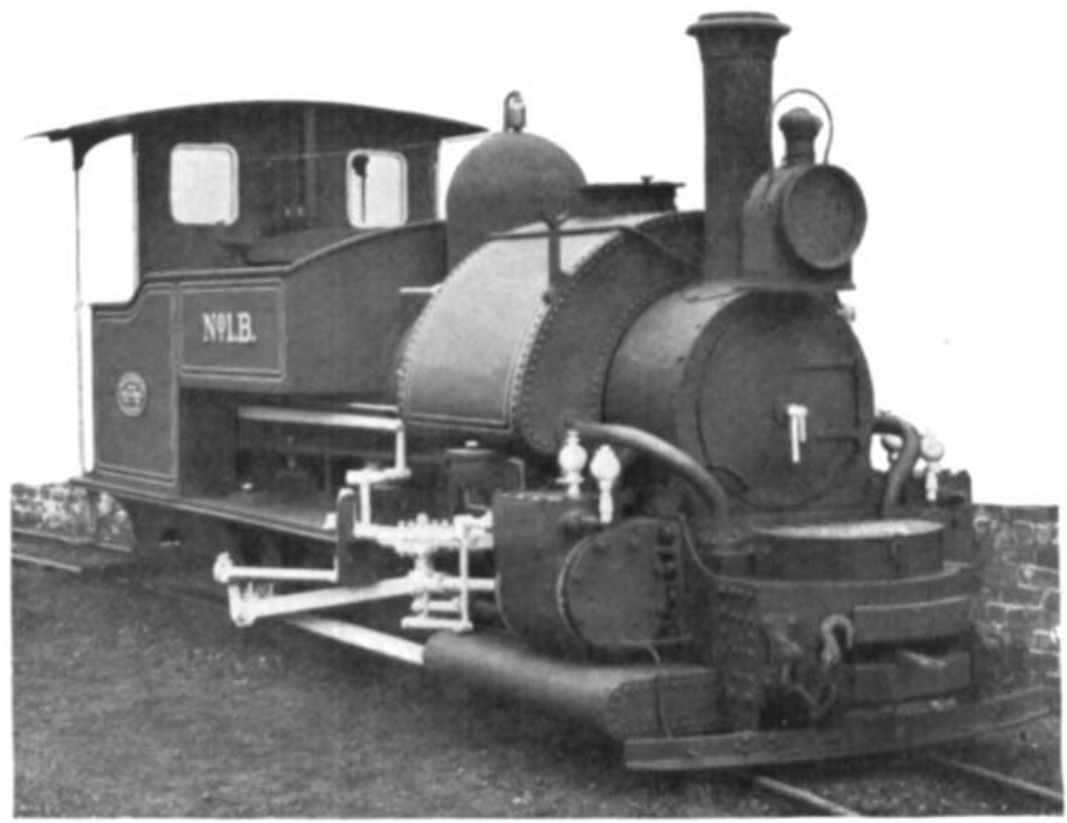

Machanical Engincers 1898. 
Cylinders

Jins. by 12 ins.

Whacls 24 ins.

II'cight 9 tons.
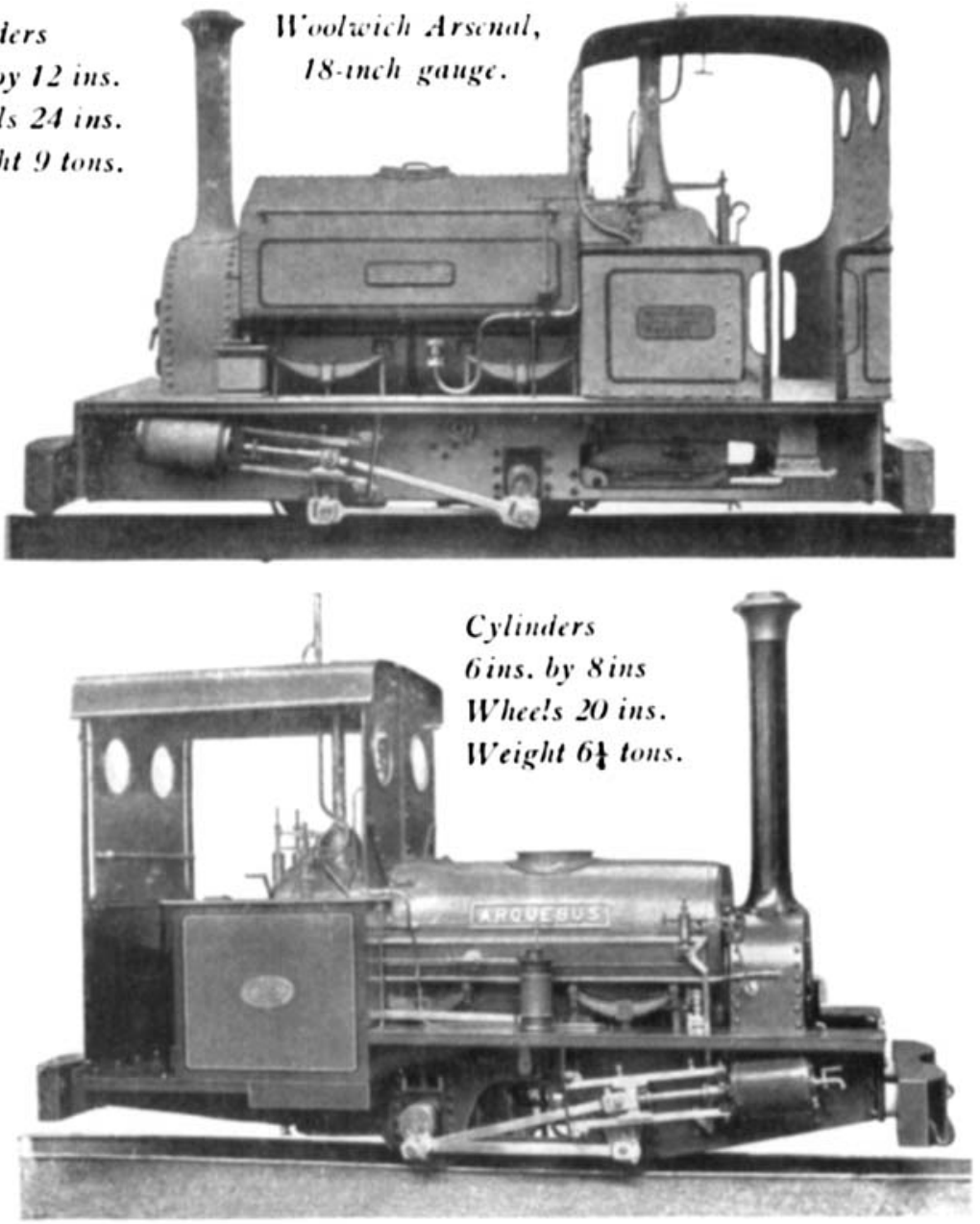

Cylinders

7 ins.by 12 ins.

II'ineels 21 ins.

IIight 8 tons.

Ioolwich Arscual,

18-ınch gauge. 
NARROW-GAUC RAILWAYS. Plate 85.

Covered Ammunition Van, Waolwich Arsenal.

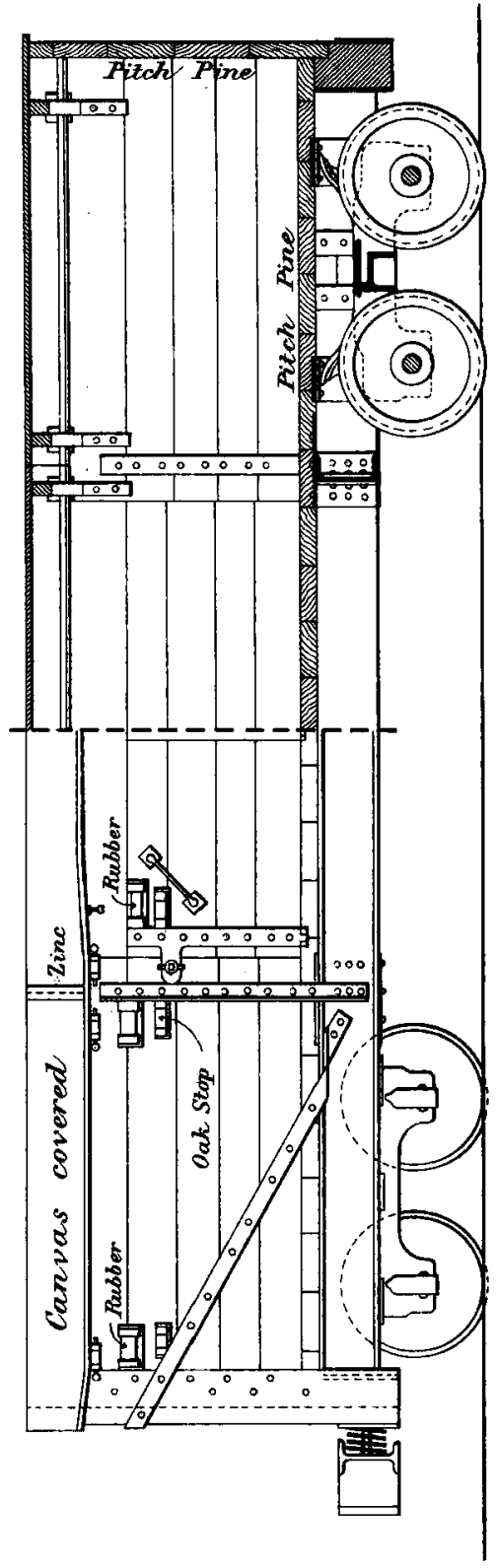

Mechanical Engineers 1898.
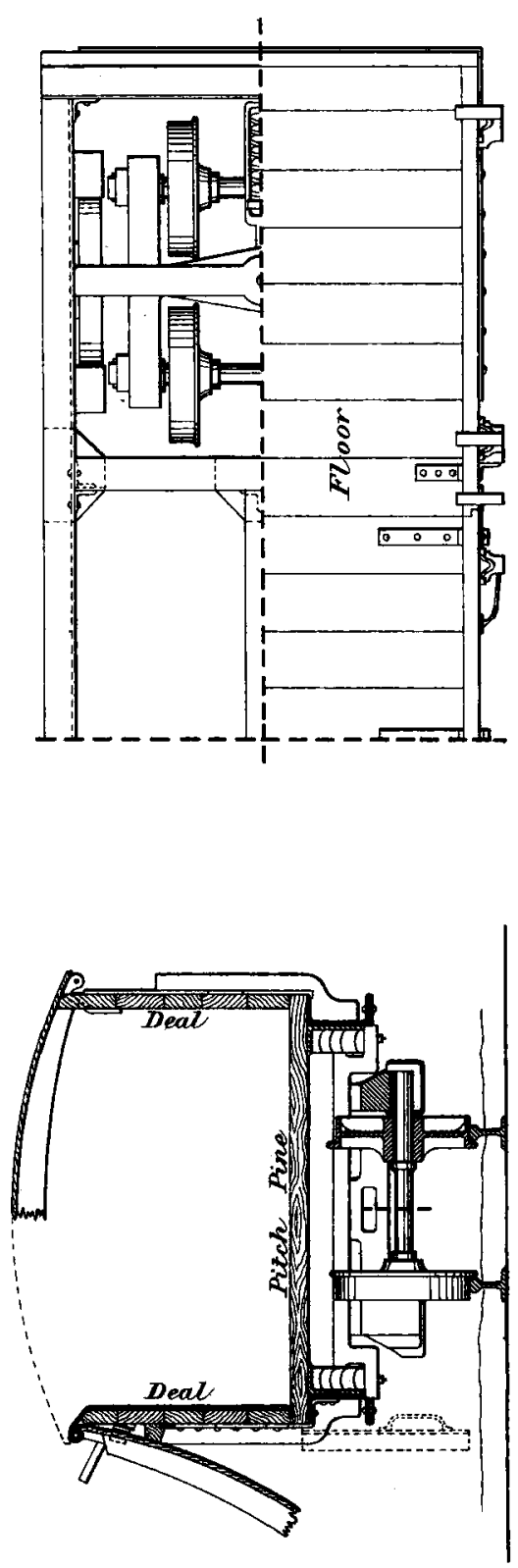

Scale $1 / 32^{\text {ned }}$ 